\title{
Supply network configuration archetypes for the circular exploitation of solid waste
}

\author{
Naoum Tsolakis
}

Centre for International Manufacturing, Institute for Manufacturing (IfM), Department of Engineering, School of Technology, University of Cambridge, Cambridge CB3 OFS, United Kingdom.

E-mail:nt377@cam.ac.uk

\section{Dimitris Zissis*}

Norwich Business School, University of East Anglia, Norwich, Norfolk, NR4 7TJ, United Kingdom.

E-mail: D.zisis@uea.ac.uk

*Corresponding author

\section{Jagjit Singh Srai}

Centre for International Manufacturing, Institute for Manufacturing (IfM), Department of Engineering, School of Technology, University of Cambridge, Cambridge CB3 OFS, United Kingdom.

E-mail: jss46@cam.ac.uk

\begin{abstract}
This research aims to use network configuration theory to propose circular supply chain archetypes for the valorisation of solid waste. The proposed network configuration archetypes are differentiated by their levels of geographic dispersion, each representing coherent clusters of waste material and supply network characteristics for the valorisation of waste streams, namely: centralised, semi-centralised and decentralised. The different types of solid waste require local (e.g. wood, organic waste), regional (e.g. glass, plastics and rubber, paper and cardboard) or pan-regional (e.g. metals and alloys) network configuration options primarily dictated by the intrinsic physico-chemical properties of the wasted material and constraints related to the processing technologies. Furthermore, the proposed network configuration archetypes dictate operational considerations, such as procurement and preprocessing options for the wasted feedstocks, along with upscale production opportunities and distribution of the value-added intermediates or end-products.
\end{abstract}

Keywords: circular supply networks; supply chain configuration archetypes; solid waste; renewable feedstocks, commercial value and viability

Reference to this paper should be made as follows: Tsolakis, N., Zissis, D. and Srai, J.S. (xxxx) 'Supply network configuration archetypes for the circular exploitation of solid waste, Int. J. Integrated Supply Management, Vol. X, No. Y, pp. $x x x x x x x x x x x x$. 


\section{N. Tsolakis et al.}

Biographical notes: Dr Tsolakis is a Research Associate at the Institute for Manufacturing (University of Cambridge), where he focuses on industrial systems and network analysis issues across a range of industrial applications and with an inter-disciplinary outlook.

Dr Zissis is an Assistant Professor in Operations Management at the Norwich Business School. His research interests lie in the field of Game Theory and its applications in Operations Management, especially in Supply Chain Management.

Dr Srai has extensive experience of leading large scale complex research projects comprising multiple stakeholders across industry, academia, and public bodies. His research team at the University of Cambridge brings an engineering and strategic operations management perspective to the design, analysis and operation of international supply chains and the impact of advanced production and digital technologies

\section{Introduction}

Global manufacturing and economic growth are at odds with environmental sustainability as they inevitably imply overexploitation of natural resources along with generation of waste streams and pollution (Moutinho et al., 2017), from an end-to-end manufacturing supply networks' perspective. In this regard, operations management scholars are exploring emerging supply chain management phenomena and evolutionary dynamics to tackle the abovementioned dyadic relation (Nasir et al., 2017; Zissis et al., 2018). Notwithstanding the progress in waste recycling and reuse, often the discarded materials either require costly and sophisticated technical treatment, or present deficient quality aspects that render landfill disposal or incineration as the ultimate waste management option (Poulikakos et al., 2017). To that end, the circular economy discourse is being propagated in the public and business agendas by emphasising the idea of exploiting waste streams and using materials in an iterative way to "achieve workable relationships between ecological systems and economic growth" (Nasir et al., 2017). Especially, the circular economy opportunity in Europe is projected at about $€ 1.8$ trillion by 2030 (Ellen MacArthur Foundation, 2015), thus indicating the emerging role of circular economy principles in the sustainable supply chain management field.

A common theme within the discourse of circular supply chains has hitherto been myopically focusing on organic feedstocks and biofuels (Srai et al., 2018), while neglecting the sustainability potential of solid waste towards formulating global value networks (Xu et al., 2017). Contingent upon the waste occurrence or origin, the main solid waste sources are categorised into two groups, namely municipal and industrial. Municipal solid waste is anticipated to reach up to 2.2 billion tons per year by 2025 (Sadef et al., 2016), denoting an increase by $69.2 \%$ compared to the current state; by that time urban population will account for over $60.5 \%$ worldwide (United Nations, 2014). In this vein, the generated industrial waste is estimated to increase from about 94 million tons in 2015 to 120 million tons by 2020 (Frost and Sullivan, 2016), on a global scale. In economic terms, the global solid waste management cost is currently US $\$ 205.4$ billion per annum with estimations indicating an increase by almost US $\$ 170$ billion by 2025 (Hoornweg and Bhada-Tata, 2012). Moreover, the long-term solid waste disposal in 
Supply network configuration archetypes for the circular exploitation of solid

waste

specific sites can cause detrimental health issues such as vector-borne diseases, dysentery and high blood lead levels (Nizami et al., 2017).

To support the development of efficient circular ecosystems, consideration of the related end-to-end network configuration perspectives is necessary to address underlining challenges (Boyer et al., 2000) and create value (Genovese et al., 2017). To that end, Tsolakis et al. (2019) mapped the end-to-end network structure for terpene-based circular value chains, further capturing potential archetypal product-process combinations. However, studies theorising circular supply network archetypes or networks with "recurring clusters of attributes" in a circular context, based on the elaborated solid waste, are lacking due to the novel and unexplored nature of the circularity concept from a value chain perspective (Srai et al., 2018).

In this study, the principal objective is to use network configuration theory to identify circular supply chain archetypes for different types of solid waste, which can be used as renewable feedstocks, and address a recognised gap in the operations management literature (Srai et al., 2018). In this regard, we firstly identify main solid waste streams available from both municipal and industrial sources for which the technical feasibility as replacements or substitutes in business applications is demonstrated, mainly at a laboratory/experimental level. Following that, we specify three fundamental solid wastedriven network configuration archetypes, presenting them as building blocks to describe emerging circular value networks for a range of feedstocks. Our research addresses the following key Research Question:

- What are the major circular supply network configuration archetypes emerging from solid waste streams?

The abovementioned question is critical to be addressed since circular supply chains appear to be feasible options in order to recover value from waste and manufacture valueadded intermediates or end-products (Genovese et al., 2017). More specifically, to answer the Research Question of this study, solid waste feedstock specifications and network implications are critically evaluated with the aim to articulate three intrinsic circular supply network configuration archetypes for the value exploitation of industrial and municipal solid waste streams; the identified archetypal forms can be differentiated by the level of the geographic dispersion of network nodes of operations.

The remainder of the paper is structured as follows. Section 2 sets out the materials and methods used in this research. Then, Section 3 performs a literature review and a critical taxonomy of both academic and institutional studies on main solid waste, while the reviewed renewable feedstocks are mapped based on their proven applicability in a circular economy context. Thereafter, Section 4 articulates the major circular supply network configurational archetypes that should be proactively explored to evaluate supply chain structural designs for circular economy applications. A discussion about the implications of this research on theory and practise, along with limitations and future research avenues, is provided in Section 5.

\section{Materials and Methods}

This research adopts a configurational outlook to specify archetypes in the supply network field, as outlined by Pathak et al. (2014). Considering that an archetype is defined as "a set of structures and systems that reflects a single interpretive scheme" 
(Greenwood and Hinings, 1993), a common set of attributes or elements should be defined to describe supply network archetypes. In this sense, we synthesise evidence from the literature, as the object of scrutiny, so as to provide validated results while revealing new research avenues (Tranfield et al., 2003). The basic terminology, theoretical lens, solid waste focus and critical taxonomy approach pertinent to this research are specified in the sub-sections below.

\subsection{Basic terminology}

Regarding network archetypes, we adopt the following definition: "an archetype is set of structures and systems that reflects a single interpretive scheme" (Greenwood and Hinings, 1993). Interpretive settings in this context relate to a set of common attributes or elements that characterise the multiple profiles of a circular supply system. Tsolakis et al. (2016) indicate that elements ranging from renewable feedstocks, to technology processing options, to markets and to commercial value and viability, could be grouped to derive circular supply network archetypes enabled by solid waste streams.

\subsection{Theoretical lens}

The configuration concept has been propagated in the corporate strategy and organizational structure literature (Srai and Gregory, 2008), predominantly by following a static focal-firm viewpoint and neglecting the evolving dynamics governing the international manufacturing scene. Srai et al. (2018) posit that a circular network configuration structure is principally dictated by the renewable feedstock followed by technology options for the conversion of waste material to value-added intermediates or end-products for ensuring commercial viability. In this sense, the search for circular network archetypes may be thought as a set of variables at a feedstock, processing and network levels that "fit" and ensure an equilibrium state in end-to-end supply chain operations. To that end, in this research, we adopt the contingency "fit" theory as gestalt perspective to supply chain management proposed by Buttermann et al. (2008), along with the methodological approach provided by Srai et al. (2018) as the theoretical lens, to propose circular network configuration archetypes defined by solid waste. Batista et al. (2019) articulated five propositions regarding circular supply chain archetypes and identified 'scope', 'focus' and 'impact' as the explanatory perspectives. In contrast, this research focuses on configuration as the underpinning archetypal form of circular supply networks.

The circular supply network configuration archetypes identified in this research are based on the level of the geographic dispersion of operations. In other words, based on a graph-theoretic perspective, a configuration archetype in this research is characterised as the proximity of nodes (renewable material sources and processing facilities) and arcs (transportation) for the valorisation of wasted solid material that further affects the associated network performance and sustainability repercussions (Kim et al., 2015). In this sense, considering the centrality of the manufacturing node for the provision of value-added intermediates or end-products, three circular supply network archetypes are proposed: (i) centralised; (ii) semi-centralised; and (iii) decentralised. The alternative network configurations can then be evaluated in terms of (Zetterholm et al., 2018): 
Supply network configuration archetypes for the circular exploitation of solid

waste

network objective; operational constraints imposed by the physico-chemical properties of the solid waste; technology and processing constraints; transportation and scheduling requirements; expected trade-offs, i.e. processing efficiency, economy of scale effects and financial viability; environmental sustainability impact.

The geographical attribute is dominant in solid waste valorisation networks considering the: (i) geographical distribution and pooling of diverse solid waste sources that dictate network optimisation objectives, e.g. supply capacity, number of collection/processing facilities, network capacity etc. (Erfani et al., 2018); (ii) geographical restrictions on solid waste logistics/transportation (Das et al., 2019); (iii) alternative legislatively and technically imposed requirements for the transportation and treatment of different solid waste in a range of geographical regions (Abdel-Shafy and Mansour, 2018); (v) variant level of infrastructure and technology readiness for solid waste collection, transportation and treatment (Zabaleta and Rodic, 2015); and (iv) local and regional environmental impact of solid waste (Singh, 2019).

\subsection{Solid waste focus}

This research focuses on major municipal and industrial wasted material, with experimentally proven applicability as replacements to fossil-based counterparts, able to realize circular paradigms in the manufacturing domain. The research focus on solid waste streams is attributed to: (i) the public entities' and private firms' legal obligations to manage their increasing volumes of the often bulky solid waste (Musee et al., 2008); (ii) the potentially economical, technical and practical facile gathering and accessibility to detailed data regarding solid waste streams (Gu et al., 2017); and (iii) the often stable neutral - nature of solid waste streams that, in most cases, does not necessitate novel and sophisticated mechanical or chemical processing pathways to be developed thus allowing the feedstocks' economic and technical feasible exploitation (Aleluia and Ferrão, 2017). In this sense, irrespective of their type, main reported solid waste streams throughout the world, from a weight standpoint, include (Hoornweg and Bhada-Tata, 2012): (i) glass; (ii) metals and alloys; (iii) paper and cardboard; (iv) plastics and rubber; (v) wood; and (vi) organic waste. The potential circular exploitation of solid waste streams may vary between developing and developed countries, but the main solid waste types are similar (Nizami et al., 2017).

\subsection{Critical taxonomy}

The aim of this manuscript is to provide a coherent conceptual construct about circular network configuration archetypes defined by solid waste via using evidence from the extant literature (Tranfield et al., 2003). In this regard, we reviewed relevant publications discussing the potential of the identified solid waste streams as renewable feedstocks in a circular economy context. To that end, Boolean searches using appropriate keywords in the Scopus ${ }^{\circledR}$ of Elsevier and Web of Science ${ }^{\circledR}$ of Thomson Reuters databases were performed; these databases enlist a broad range of high impact scientific journals in the fields of Natural Sciences and Engineering (Mongeon and PaulHus, 2016). Each of the identified waste material feedstock was searched either 
separately or in combination with the terms "circular supply chain", "circular supply network", "replacement" and "substitute" by using either the "Article Title" or "Article Title, Abstract, Keywords" categories. The date range was set from "All years" to "Present", while all document types and subject areas were selected. The analysis was restricted to publications that are written in the English language while the retrieved journal articles were counterchecked to increase consistency. By $15^{\text {th }}$ of May 2018 our initial search generated in total 6,679 results (waste glass -568 papers; waste metals and alloys - 1,086 articles; waste paper and cardboard - 637 studies; waste plastics and rubber $-2,803$ papers; waste wood -444 works; and (vi) organic waste $-1,141$ studies). Following an initial screening of the publications' title, abstract and keywords, the collected articles were accepted or rejected for further review to identify alternative value-added applications for each solid waste stream. Notably, we could not retrieve any scientific publications focusing on the archetypal design of circular value networks from a feedstock perspective, while we could observe the proliferation of the terms "circular economy" and "circular supply chain (or network)" in the academic literature during the last five years.

\section{Solid Waste in Circular Supply Chain Applications}

In this section, we provide a first generic overview of major solid waste streams and their potential value-added applications for the design of circular supply networks. These materials include: (i) glass; (ii) metals and alloys; (iii) paper and cardboard; (iv) plastics and rubber; (v) wood; and (vi) organic waste.

\subsection{Glass}

Municipal waste streams, and especially discarded electrical and electronic products (commonly referred as e-waste), across the globe generate million tons of glass waste on an annual basis (Tansel, 2017). Indicatively, in 2014, the total glass waste in the European Union was about 18.5 million tons (Eurostat, 2019) while in the United States of America the respective volume was around 11.5 million tons (EPA, 2016). Glass recycling could be a viable option to tackle the challenge of wasted glass streams, but the discarded glass usually contains hazardous substances, like mercury $(\mathrm{Hg})$, that render its recycling problematic and uneconomical. To that end, considering the non-biodegradable nature of glass, its silica composition, the multiple availability sources of wasted glass and its non-economic viable disposal at landfills, glass waste could be used as potential feedstock for engineering applications.

Primarily, research works describe the valorisation opportunities for waste glass in the ceramics sector owing to a range of benefits (Andreola et al., 2016), including: (i) lower use of water resulting in lower cracking defects and increased mechanical strength; (ii) increased workability enabling the production of artistically finer products with aesthetic surface texture; (iii) lower firing durations and temperatures resulting in decreased production costs; and (iv) elimination of flux and inert materials whose extraction and transportation associate to significant environmental impacts. Furthermore, studies document the potential of glass waste for manufacturing cement, a key ingredient in the construction industry (Sadiqul Islam et al., 2016), due to: (i) reduced cement 
Supply network configuration archetypes for the circular exploitation of solid waste

production cost by $14 \%$ (for a $50 \mathrm{~kg}$ cement bag); (ii) reduced cement production related $\mathrm{CO}_{2}$ emissions by $18 \%$; and (iii) increased concrete's compressive strength by $14 \%$. Recently, the utilisation of waste glass in producing geopolymers, i.e. novel materials for a range of fire- and heat-resistant applications associates to a range of benefits (Novais et al., 2016), including: (i) lower production cost; (ii) 'green' manufacturing; and (iii) increased compressive strength by up to $46 \%$, under specific curing conditions.

Moreover, market requirements for novel materials in the acoustic insulation, energy storage and thermal insulation domains provide grounds for exploiting glass waste streams (D'Amore et al., 2017). In particular, utilisation of glass waste in the manufacturing sector associates to: (i) low production cost due to lower energy and chemicals' consumption; (ii) low carbon footprint; (iii) improved acoustic properties due to the novel material's structure; (iv) reduced transportation and storage costs due to the small thickness of the manufactured panels that further allows reductions in dimensions; (v) eliminated emissions of dust or fibres; and (vi) enhanced thermal insulation due to the small cell microstructure of the manufactured panels. Finally, progress is made towards using glass waste for the synthesis of high-purity ferrosilicon (i.e. iron-silicon) alloys which are used to produce metals (Farzana et al., 2014). The critical taxonomy of studies discussing the circular potential of glass waste streams is presented in Table 1.

Table 1 Glass waste as renewable feedstock to key circular value network applications.

\begin{tabular}{|c|c|c|}
\hline Material & Application & Indicative References \\
\hline \multirow[t]{5}{*}{ Glass } & - Ceramics & $\begin{array}{l}\text { Andreola et al. (2016); Kim et al. (2016); Marinoni et } \\
\text { al. (2013); Mymrin et al. (2016); Wiemes et al. (2017) }\end{array}$ \\
\hline & $\begin{array}{l}\text { - Cement and } \\
\text { concrete }\end{array}$ & $\begin{array}{l}\text { Aliabdo et al. (2016); Choi et al. (2017); Lu et al. } \\
\text { (2017); Sadiqul Islam et al. (2016); Torres-Carrasco } \\
\text { and Puertas (2017); Yu et al. (2016) }\end{array}$ \\
\hline & - Geopolymers & $\begin{array}{l}\text { Avila-López et al. (2015); El-Naggar and El-Dessouky } \\
\text { (2017); Novais et al. (2016); Tchakouté et al. (2016); } \\
\text { Vafaei and Allahverdi (2017) }\end{array}$ \\
\hline & $\begin{array}{l}\text { - Insulation and } \\
\text { energy storage }\end{array}$ & $\begin{array}{l}\text { D'Amore et al. (2017); Gutierrez et al. (2016); Memon } \\
\text { et al. (2013) }\end{array}$ \\
\hline & $\begin{array}{l}\text { Ferrosilicon } \\
\text { alloys }\end{array}$ & Farzana et al. $(2014 ; 2016)$ \\
\hline
\end{tabular}

\subsection{Metals and alloys}

Utilisation of wasted metals and alloys, available either as industrial by-products or as scrap, in various applications is receiving research attention. Below, we discuss each of the major discarded metals, i.e. steel, iron, cooper, and aluminium, that are normally used as aggregates and could fuel circular supply network opportunities. The critical taxonomy of studies discussing the circular potential of wasted metals and alloys is presented in Table 2 . 


\subsubsection{Steel}

The global production of stainless steel increased from less than 20 million tons to over 40 million tons during the last fifteen years, thus rendering stainless steel as the highest utilised material on a global scale (ISSF, 2016). Albeit the $100 \%$ recyclability of stainless steel, its widespread use in the construction and industrial sectors relates to considerable waste volumes with hazardous by-products like chromium, lead, nickel and cadmium (Huaiwei and Xin, 2011). Therefore, solutions that provide added-value to the large wasted amounts of stainless steel and by-products thereof should be navigated.

The composition of steel slag is proven compatible with common clay, thus allowing the use of the respective wastage as alternative raw material in ceramics in order to (Galán-Arboledas et al., 2017): (i) increase porosity to minimise cracks and increase flexural strength; (ii) consume less energy, water and raw clay materials; (iii) reduce greenhouse gas emissions due to lower fuel consumption; and (iv) lower operational cost for both steel and ceramics industries. Additionally, steel waste is reported to be a desirable supplementary cementitious material or aggregate in concrete (Sengul et al., 2016), either in the form of fibres or slag. The addition of steel waste allows to harness improvements in compressive strength, flexural strength and splitting tensile strength in reinforced concretes with cost savings by up to $90 \%$ compared to commercial concrete mixtures.

\subsubsection{Iron}

In 2014, according to a survey conducted by the United Nations University, about 16.5 million tons of iron could be found in global e-waste streams (Collins and Kuehr, 2015), without considering the wasted iron ore tailings and iron powder occurring as byproducts during manufacturing operations. Iron waste does not only have serious pollution and health repercussions but can also promote economic value creation in case efficient circular supply networks are established.

Interestingly, studies demonstrate the potential of iron waste as rare earth in the field of ceramics to enhance desirable material properties (da Silva et al., 2014), including: (i) increased flexural strength; (ii) decreased density; (iii) increased porosity; and (iv) decreased water absorption. Furthermore, exploiting iron waste for concrete manufacturing is a decent overture to its disposal due to the resulting concrete's (Singh and Siddique, 2016): (i) decreased workability owing to the increased friction among particles; (ii) increased compressive strength with iron slag content up to 21\%; (iii) decreased water absorption due to denser internal structure; and (iv) increased resistance to chloride ion penetration.

\subsubsection{Copper}

Copper waste is obtained during copper metal processing with estimations indicating that about 2.2 to 3 tons of copper waste are produced per ton of refined copper (Shi et al., 2008). In this regard, the worldwide copper waste generation in 2015 was approximately 68.7 million tons, only from the copper industry (Sharma and Khan, 2017).

Wasted cooper slag is reported as a fine aggregate to high performance concrete as it results in increased density, workability and decreased surface water absorption (Al-Jabri 
Supply network configuration archetypes for the circular exploitation of solid waste

et al., 2009). More specifically, copper slag in clinker production can act as iron adjusting and mineralising component while improving the clinker grindability; in case of cement replacement the resulting mortar and concrete have decent performance compared to ordinary Portland cement (Shi et al., 2008).

\subsubsection{Aluminium}

Global demand for aluminium demonstrates a continuously increasing trend with the global production of the metal exceeding the 58 million tons in 2016 (U.S. Geological Survey, 2018), while projections indicate a total demand of about 97 million tons in 2020 (International Aluminium Institute, 2009). Annually, more than 5 million tons of aluminium dross, a by-product of the aluminium smelting process, is generated globally (Murayama et al., 2012); although consisting a waste, dross contains aluminium and other valuable elements (i.e. aluminium oxides) that could be exploited in value-added applications.

As aluminium can be infinitely recycled without compromising its properties, studies focus on the exploitation of aluminium dust that is often forwarded for landfill disposal. In this regard, aluminium dust is mainly used as a foaming agent to substitute the costly aluminium powder and for the synthesis of autoclaved aerated concrete without compromising any mechanical properties (Liu, Leong et al., 2017). In addition, the preparation of calcium aluminate cement mixes from aluminium dross is reported to result in cement mixtures that satisfy the cementing and refractory properties specified by international standards (Ewais et al., 2009).

Table 2 Wasted metals and alloys as renewable feedstock to key circular value network applications.

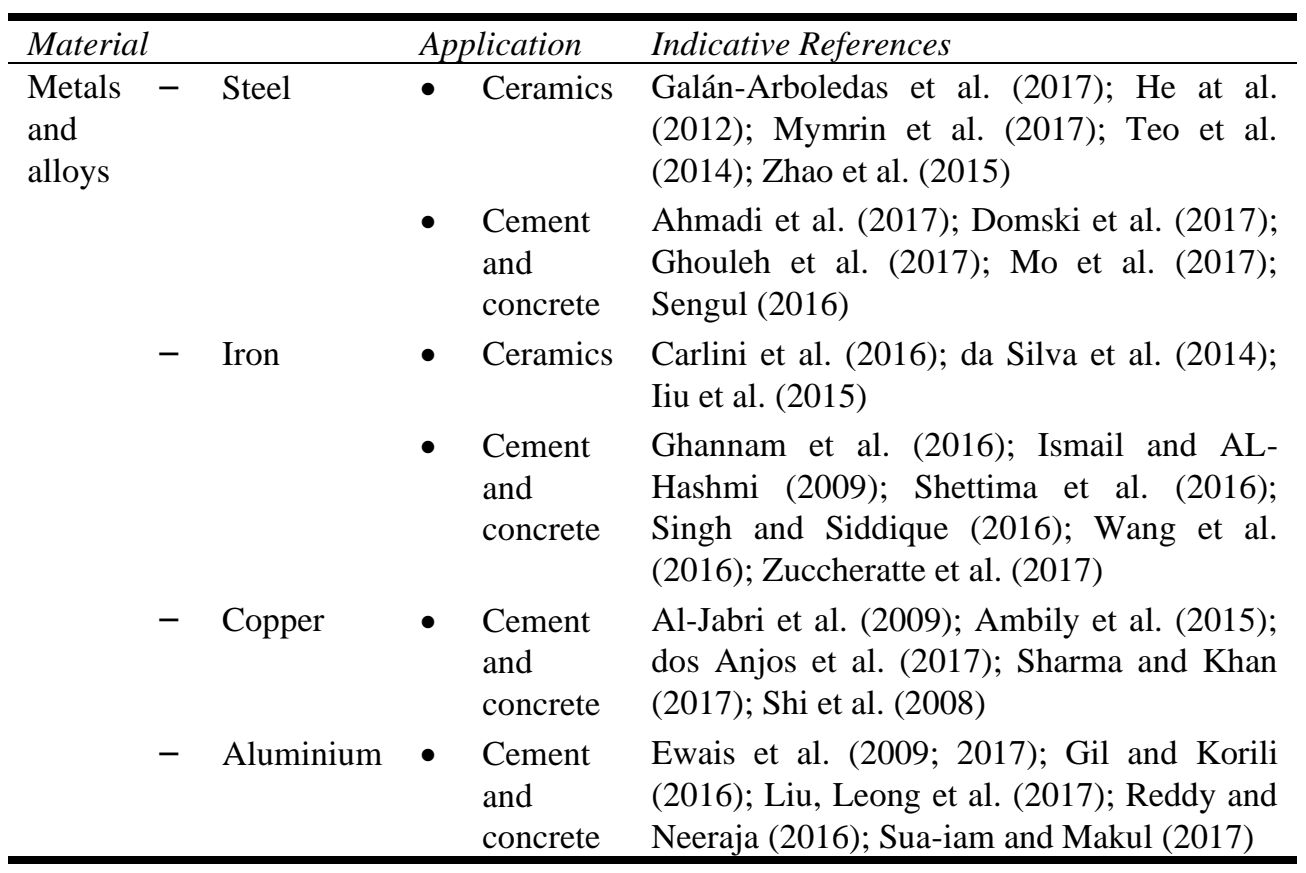




\subsection{Paper and cardboard}

In Europe, the paper and cardboard per capita consumption was about $137 \mathrm{~kg}$ in 2012 with the global per capita consumption averaging at $56.8 \mathrm{~kg}$ (Magnaghi, 2014). The main sources of recovered paper and cardboard are industry and businesses (52\%), households (38\%), and offices (10\%). As paper and cardboard waste is often rejected from recycling facilities due to the significant volumes of contaminants like food, grease, plastic and metals, the high fibre content renders it appropriate for added-value engineering applications (Pivnenko et al., 2016).

Rodriguez et al. (2017) investigated the biological pretreatment of paper waste to produce biogas as the process improves process efficiency by up to $21 \%$ and reduces the cost so that a positive energy balance is obtained compared to non-pretreated biomass. The main paper and cardboard waste pretreatment methods for biofuels and bioenergy production are classified as mechanical, ultrasounds, microwave, thermal, chemical and biological, with the mechanical techniques being the most efficient. Liu, Qing et al. (2017) reported the suitability of paper waste for applications in electronics owing to the porous structure of paper that allows the deposition of conductive fillers hence rendering paper waste electrically conductive. The main specifications that motivate the use of cellulose paper as a versatile substrate in electronic applications are summarised to the following: (i) light weight; (ii) bio-friendliness; (iii) mechanical bendability; (iv) unique material structure that facilitates the electrical quality improvement process; and (v) low cost and simple fabrication process.

In addition, Khorami et al. (2017) reported that the incorporation of Kraft pulp fibres, extracted from cardboard waste, results in cement boards with slightly increased tensile strength and longer anchorage length. Especially, the intrinsic hydrophilic properties of the fibres allow the efficient incorporation of other compounds like glass fibres and nanosilica fumes for achieving even more increased flexural behaviour of cement composite boards. Finally, Joshi et al. (2017) reported the successful conversion of paper waste into upgraded and high quality cycyanoethyl cellulose for a variety of applications. The critical taxonomy of studies discussing the circular potential of paper and cardboard waste is presented in Table 3 .

Table 3 Paper and cardboard waste as renewable feedstock to key circular value network applications.

\begin{tabular}{|c|c|c|}
\hline Material & Application & Indicative References \\
\hline \multirow[t]{4}{*}{$\begin{array}{l}\text { Paper and } \\
\text { cardboard }\end{array}$} & $\begin{array}{c}\text { - Biofuels and } \\
\text { bioenergy }\end{array}$ & $\begin{array}{l}\text { Argun and Onaran (2016); Brummer et al. (2014); } \\
\text { Hao and Mi (2016); Nishimura et al. (2017); } \\
\text { Rodriguez et al. (2017) }\end{array}$ \\
\hline & - Electronics & $\begin{array}{l}\text { Lessing et al. (2014); Liao et al. (2015; 2016); Liu, } \\
\text { Qing et al. (2017); Su et al. (2017) }\end{array}$ \\
\hline & $\begin{array}{l}\text { - Cement and } \\
\text { concrete }\end{array}$ & $\begin{array}{l}\text { Khorami et al. (2017); Martínez-Lage et al. (2016); } \\
\text { Rajput et al. (2012); Simão et al. (2017); Wong et al. } \\
\text { (2015) }\end{array}$ \\
\hline & $\begin{array}{l}\text { - Cellulose- } \\
\text { based } \\
\text { materials }\end{array}$ & $\begin{array}{l}\text { Elliston et al. (2013); Joshi et al. (2017); Sun et al. } \\
\text { (2016); Yeon et al. (2014) }\end{array}$ \\
\hline
\end{tabular}


Supply network configuration archetypes for the circular exploitation of solid waste

\subsection{Plastics and rubber}

The worldwide plastics consumption reached 322 million tons in 2015 with an observed annual increase of about 4\% during the last decade (Sharuddin et al., 2017). Additionally, considering that rubber demand is projected to exceed supply by 2020 (Dobrotă and Dobrotă, 2017), along with the close interrelation between oil and rubber prices, implications about the need to devise circular operational models to retain the industry's viability are evident. Almost 1,000 million tires are being disposed on an annual basis with an estimated $50 \%$ not being reclaimed, thus raising great health and ecological issues due to the rubber's weatherproof and non-biodegradable nature (Girskas and Nagrockienè, 2017).

Sienkiewicz et al. (2017) reviewed the environmentally friendly composites obtained from rubber waste granulates. Depending on the type of waste, processing options (e.g. cryogenic or ambient-temperature grinding, retreading, sintering etc.), available volumes, size and morphology of the resulting particles, applications include street furniture and gardening solutions, automobile linings and roofing materials. The mechanical properties of the final polymer applications depend upon the amount of the reclaimed rubber granulates.

From an intermediate or end-product perspective, Bulut and Şahin (2017) studied the use of e-plastic waste as part of the filling materials on polymer concrete and found that for different e-plastic/filling material ratios the compressive, flexural and splitting tensile strength vary according to the e-plastic content. From an alternative end-of-life product perspective, Dehghanian and Mansour (2009) studied the recovery of scrap tires as a fuel substitute in cement plants and concluded that technology type and location of recycling plants determines the optimal supply network configuration. The critical taxonomy of studies discussing the circular potential of plastics and rubber waste is presented in Table 4.

Table 4 Plastics and rubber waste as renewable feedstock to key circular value network applications.

\begin{tabular}{|c|c|c|}
\hline Material & Application & Indicative References \\
\hline \multirow{3}{*}{$\begin{array}{l}\text { Plastics } \\
\text { and } \\
\text { rubber }\end{array}$} & $\begin{array}{l}\text { - Polymer- } \\
\text { composites }\end{array}$ & $\begin{array}{l}\text { Dehghanian and Mansour (2009); Sienkiewicz et al. } \\
\text { (2017); Yehia et al. (2004) }\end{array}$ \\
\hline & $\begin{array}{l}\text { - Cement and } \\
\text { concrete }\end{array}$ & $\begin{array}{l}\text { Al-Tulaian et al. (2016); Bhogayata and Arora (2017); } \\
\text { Bulut and Şahin (2017); Hama and Hilal (2017); Saikia } \\
\text { and de Brito (2012) }\end{array}$ \\
\hline & - Fuels & $\begin{array}{l}\text { Ayanoğlu and Yumrutaş (2016); Aydin and Ilkiliç (2015); } \\
\text { Dehghanian and Mansour (2009); }\end{array}$ \\
\hline
\end{tabular}

\subsection{Wood}

In the European Union, around 50 million cubic meters of wood waste are generated on an annual basis (Bergeron, 2016), with significant volumes being disposed in landfills (Michaud et al., 2010). The high availability of low-cost contaminated wood waste is nowadays non-preferable thus motivating research towards the exploitation of these 
waste streams in added-value applications (Garcia and Hora, 2017), as opposed to the traditional incineration solution.

Novais et al. (2015) reported the fabrication of lightweight ceramic tiles by using wood waste as porogen with the following derived benefits: (i) reduction in tiles' weight by up to $12.5 \%$; (ii) achievement of tiles' thermal conductivity by about $76 \%$; (iii) increase in thermal comfort inside buildings; and (iv) reduction in tiles' logistics costs. In addition, Ramos et al. (2013) reported that the partial cement replacement by wood waste ash (up to $20 \%$ ) resulted in neither workability nor strength loss. The resulting mortar mixtures presented equivalent compressive and attractive strength activity to Portland cement mixture while the carbonation depth was greater. The critical taxonomy of studies discussing the circular potential of wood waste is presented in Table 5.

Table 5 Wood waste as renewable feedstock to key circular value network applications.

\begin{tabular}{|c|c|c|}
\hline Material & Application & Indicative References \\
\hline Wood & $\begin{array}{l}\text { - Ceramics } \\
\text { - Cement and } \\
\text { concrete }\end{array}$ & $\begin{array}{l}\text { Novais et al. (2015); Wiemes et al. (2017) } \\
\text { Ban and Ramli (2011); Elinwa and Mahmood (2002); } \\
\text { Martínez-Lage et al. (2016); Ramos et al. (2013); Wang et } \\
\text { al. (2017) }\end{array}$ \\
\hline
\end{tabular}

\subsection{Organic matter}

Approximately $46 \%$ of the globally generated solid waste is organic (Hoornweg and Bhada-Tata, 2012). Especially, food waste presents an interesting case as it associates with social, nutritional and environmental issues; today, one-third of the global food production, around 1.3 billion tons, is wasted on an annual basis (FAO, 2011). Organic waste, according to the elaborated conversion processes (Dahiya et al., 2018), is reported to be able to act as a substrate/source towards a myriad of key applications, including: (i) biofuels (Karmee, 2016); (ii) commodity chemicals (Lee et al., 2014); (iii) added-value chemicals (Tsolakis and Srai, 2017); (iv) biohydrogen (Pasupuleti et al., 2014); (v) bioelectricity (Moqsud et al., 2013); and (vi) biodegradable plastics (Ravindran and Jaiswal, 2016). A detailed analysis of the plethora of commercial intermediates or endproducts stemming from organic waste extends the scope of this study and thus we focus on main engineering applications like biofuels, fertilisers and polymers.

Predominantly, bioengineering science investigates novel technologies and costeffective processes for the recovery of food waste as a renewable energy source to substitute fossil energy (Zhang et al., 2016). In the same vein, Karmee (2016) evaluated the technical feasibility and policies for the preparation of liquid biofuels from food waste. Furthermore, Lupton (2017) provided a multi-disciplinary literature review and reported the economic utilisation of organic fertilizers, derived from organic municipal waste, as a viable alternative to chemical fertilisers or soil improvers.

Organic waste also presents an interesting case for the production of polyhydroxyalkanoates, i.e. plastic-like materials that are perfect replacements for petroleum-based counterparts, as they are inexpensive and readily available sources of carbon. Indicatively, wheat bran and potato waste (Van-Thuoc et al., 2008), and waste from tequila bagasse (Munoz and Riley, 2008) or grass (Davis et al., 2013), have been used as substrates for the synthesis of polyhydroxyalkanoates. The critical taxonomy of studies discussing the circular potential of organic waste is presented in Table 6. 
Supply network configuration archetypes for the circular exploitation of solid waste

Table 6 Organic waste as renewable feedstock to key circular value network applications.

\begin{tabular}{llll}
\hline Material & Application & Indicative References \\
\hline $\begin{array}{l}\text { Organic } \\
\text { waste }\end{array}$ & $\bullet \quad$ Biofuels & $\begin{array}{l}\text { Abd-Alla et al. (2017); Hegde et al. (2018); Karmee (2016); } \\
\text { Svanberg et al. (2018); Zhang et al. (2016) }\end{array}$ \\
& $\bullet \quad$ Fertilisers & $\begin{array}{l}\text { Chiang et al. (2016); Cucina et al. (2018); Jimenez et al. } \\
\text { (2017); Lupton (2017); Neugebauer and Sołowiej (2017) } \\
\end{array}$ \\
& $\bullet \quad$ Polymers & $\begin{array}{l}\text { Cesário et al. (2014); Davis et al. (2013); Munoz and Riley, } \\
\text { (2008); Sindhu et al. (2013); Van-Thuoc et al. (2008) }\end{array}$ \\
\hline
\end{tabular}

\section{Circular Supply Network Configuration Archetypes}

Solid waste feedstocks provide the capability to adopt competitive supply chain structures, driven by institutional arrangements and consumer-centric preferences, further allowing firms to be responsive to market needs. According to the supply chain configuration mapping toolset suggested by Srai and Gregory (2008), the configuration of circular networks arising from solid feedstock platform technologies should focus on the following criteria to enable value delivery, including:

- Emphasis: network nodes and links

- Attributes: relevant tiers; central firm

- Scope: market; product family; supply chain processes; replenishment/innovation/product life cycles.

In a traditional supply chain, natural raw materials are processed and transformed to intermediates or final offerings with the chain being characterised by a linear flow of goods from suppliers to consumers in a "take-make-dispose" resource model (Ellen Macarthur Foundation, 2015; Zissis et al., 2015). Alternatively, in the circular economy discourse, we argue that novel -circular- networks are designed based on a robust decision-making process that supports the creation of novel links among disintegrated traditional-linear supply chains (Srai et al., 2018). More specifically, a circular supply network focuses on the exploitation of wasted material outputs, on every network echelon, to apply operations that transform these renewable feedstocks into value-added inputs for existing/innovative intermediates or end-products in other manufacturing sectors, as illustrated in Figure 1. In this sense, inspired by Srai and Gregory (2008), novel circular networks motivate radical business models that need to ensure the following six key elements:

i. Robust structure of the respective circular supply network.

ii. Continuous flow of feedstocks, information and value-added offerings.

iii. Effective enabling processes and product innovation.

iv. Stable network governance and transparent inter-relationships among key partners.

v. Streamlined compliance with internal goals and external drivers.

vi. "Value-structure" of the resulting intermediates or end-products. 


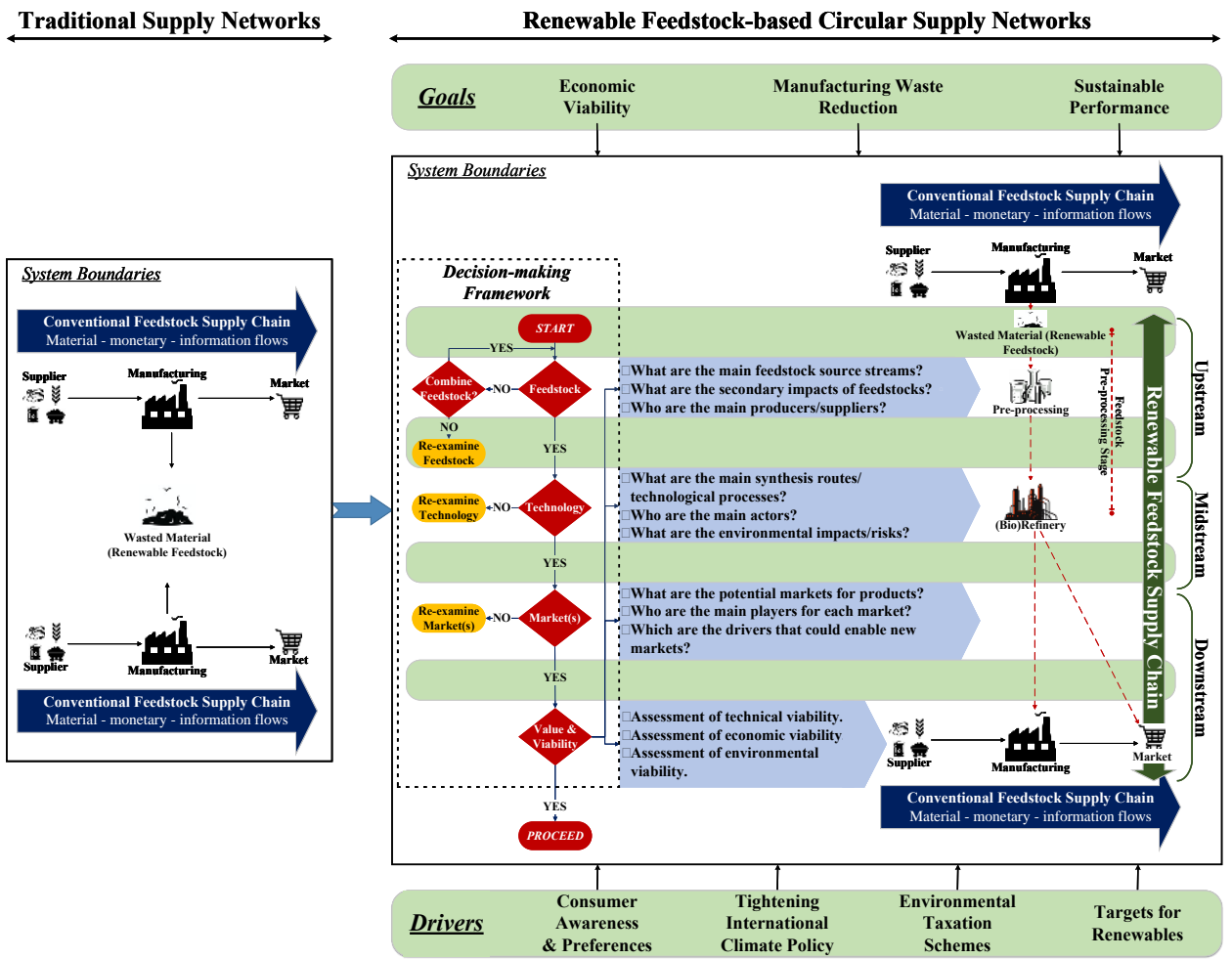

Figure 1 Framework for designing circular supply networks defined by solid waste [Adapted from Tsolakis et al. (2016)].

Confirming the findings of Koolivand et al. (2017), our study reveals that promising waste streams towards the realisation of commercially viable networks from a circular economy perspective include: (i) glass; (ii) metals and alloys; (iii) paper and cardboard; (iv) plastics and rubber; (v) wood; and (vi) organic waste. However, a milestone in circular supply chain research is the recognition of potential network archetypes as the combined result of strategic design and emergent wasted feedstock instances (Kao et al., 2017). In this end, we recognise three basic circular supply network configuration archetypes emerging from the identified renewable feedstocks, namely: (i) centralised; (ii) semi-centralised; and (iii) decentralised. The scope of the proposed network archetypes varies and depends on the geographical proximity among the involved echelons of operations (as network nodes) and to the markets to be served. In particular, centralised circular supply network archetypes typically serve global markets whereas decentralised networks usually target regional markets. In semi-centralised network archetypes nodes have different levels of operational autonomy to serve glocal market needs.

\subsection{Centralised configuration}

Centralised circular supply networks are usually characterised by a star topology where processing and stocking inventory are managed at a central point (see Figure 2). In case 
Supply network configuration archetypes for the circular exploitation of solid waste

of manufacturing end-products, secondary material is also delivered to the central node where assembly occurs. From a renewable feedstock viewpoint, centralised network structures are recommended for materials that allow industrial level production for harnessing economic benefits due to the realisation of economies of scale serving global markets. Indicatively, for the case of biogas production from sugar beet in Denmark, Skovsgaard and Jacobsen (2017) reported that the upscaling of the centralised plant from about 110,000 tones of annual inputs to around 500,000 tones resulted in capital and operational expenditures' reduction by $16-18 \%$. Notwithstanding the economic prospects, the uncertainty about the homogeneity of the elaborated feedstocks' physio-chemical and environmental qualities, which are collected from dispersed sources, raises questions regarding the capability to maintain steady operational conditions and utilisation efficiency (Parajuli et al., 2017). For example, the cellulose-to-lignin ratio in straw and willow is a detrimental factor that qualifies them as suitable for sugar-based biorefinery platforms (Parajuli et al., 2015). In this regard, centralised networks usually have the financial capacity to invest in resource integration and information collaboration initiatives, like cloud-based platforms, to develop proprietary sustainability-related databases and in-house expertise as core competences (Xing et al., 2016). Furthermore, Ye et al. (2016) investigated the use of coordination contracts between a biofuel producer and multiple small-scale farmers, finding that in centralised networks the power to coordinate contractual agreements with suppliers can more effectively secure operations and profits from feedstock availability fluctuations in comparison to decentralised systems.

Centralised networks usually serve global markets and thus have to conform to global quality standards and certification schemes. To that end, stakeholders are characterised by an inclination to invest in scheduled maintenance protocols, effective equipment and manpower training that overall promote professional quality control, both in terms of the supplied renewable feedstock and in terms of the derived intermediates or end-products. Overall, centralised circular networks imply the direct supervision of a central organisation with the network-level objective to band together firms and enable resource pooling. Managerial tools like contract timing and delivery requirements enable coordinated production partnerships that can ensure significant processing rates of wasted feedstocks and high production outputs to attain economies of scale. 


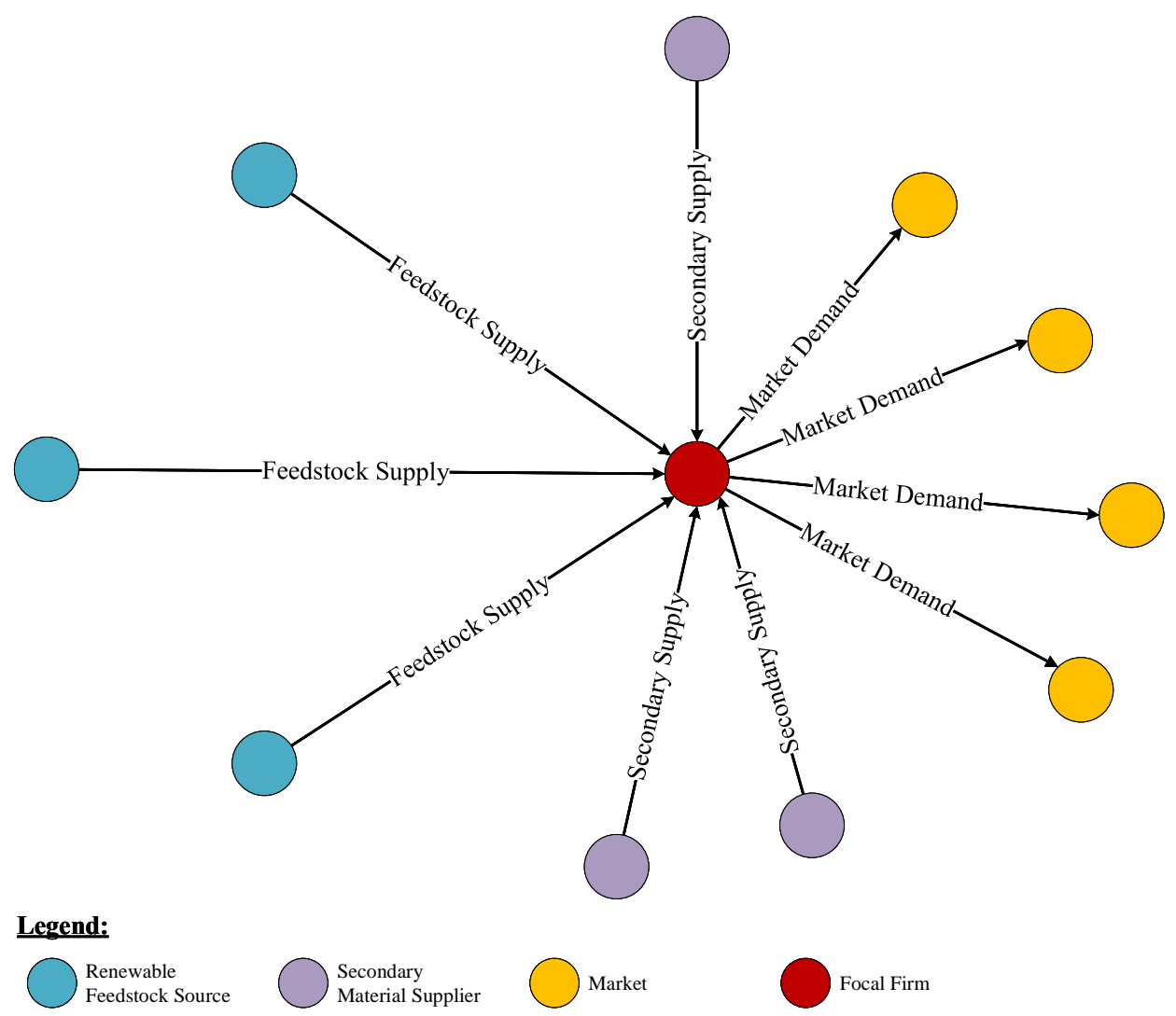

Figure 2 Circular supply network archetypes - Centralised configuration.

\subsection{Semi-centralised configuration}

Semi-centralised circular supply networks comprise of subunits with different levels of operational autonomy blending dispersed integration with local responsiveness (Liu and Song, 2017). On the one hand, renewable feedstock suppliers have a certain degree of autonomy dictated by the adaptation to local waste generation characteristics (i.e. location and availability rate). On the other hand, the central planner coordinates the subunits and articulates conforming regulations (see Figure 3). Secondary material suppliers provide the necessary components in case of manufacturing end-products.

The renewable feedstock in semi-centralised archetypes allows for the considerable production of value-added intermediates or end-products that can serve regional (i.e. nationwide level) applications. The often-biodegradable nature of the renewable feedstock along with the strict technology and production requirements do not allow the realisation of globally distributed upstream networks. Downstream the supply network, physico-chemically stable and expensive intermediates or end-products can be used to serve global market requirements.

Generally, in semi-centralised circular networks a central organisation initiates supply chain cooperative relationships to facilitate knowledge and material flows via different 
waste

management strategies (Liu and Song, 2017). Network coordination by nature exists in a dynamic balance between the supply and demand sides as the timelines and volumes of the renewable feedstocks' availability may vary, while the collection and distribution of the waste volumes needs to be streamlined with supply to enable near optimal inventories, processing efficiency and high quality of the resulting intermediates or endproducts.

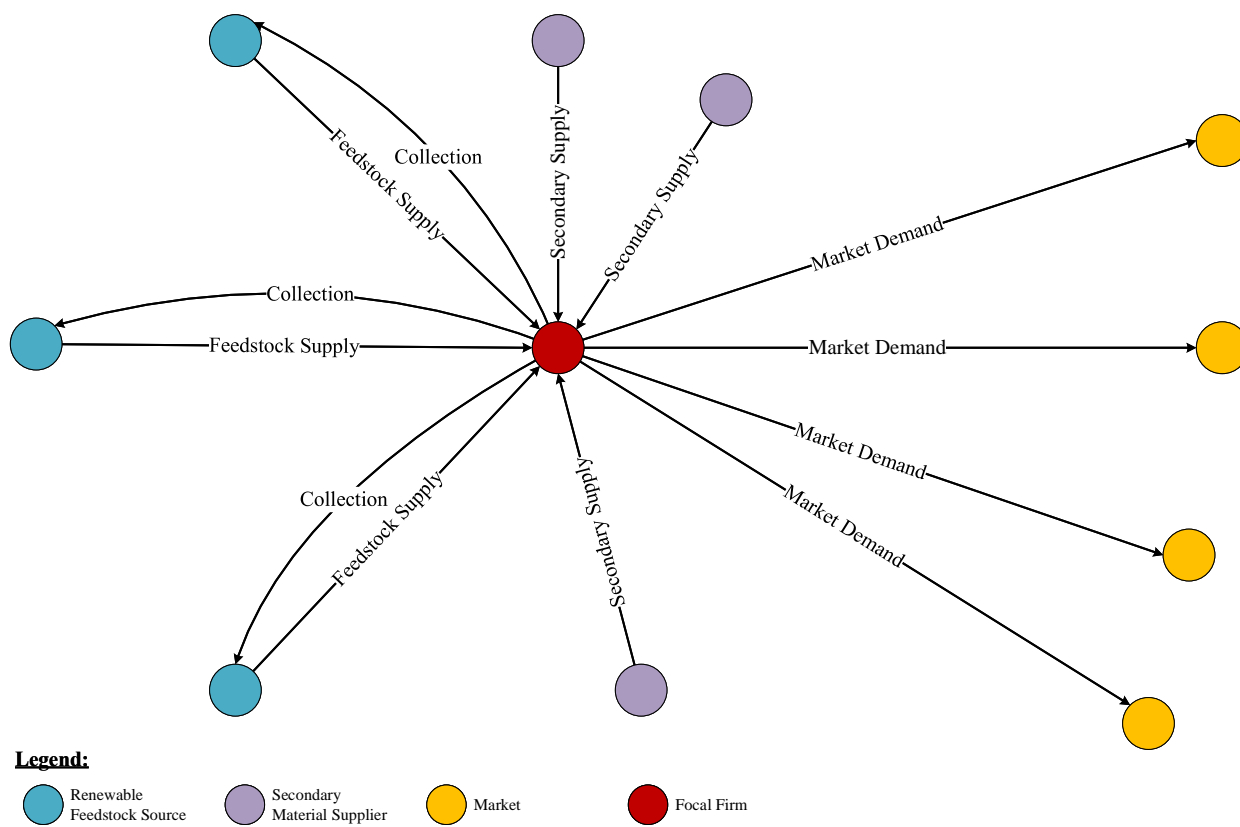

Figure 3 Circular supply network archetypes - Semi-centralised configuration.

\subsection{Decentralised configuration}

Decentralised circular supply networks are defined as local agglomerations of institutional and business actors usually focusing on servicing regional markets for direct waste treatment, valorisation and consumption (Geunes et al., 2016). The stakeholders exchange information and interact to create a community ecosystem that provides direct interfaces between renewable feedstock suppliers, processors and market stakeholders. The dispersed availability of wasted renewable feedstock sources, the requirement for multiple processing stages and the nature of the feedstocks that allows facile transportation in small distances, enable the development of locally distributed networks to fulfil local market needs (see Figure 4). Owing to the geographical proximity of echelons of operations, exploitation of renewable feedstock types that are prone to deterioration effects is feasible. Secondary material is also delivered to the central node where assembly of end-products might occur.

In sum, decentralised circular networks comprise of several stakeholders with few direct operational linkages. The primary network-level objective is to identify and exploit an assortment of value-added renewable feedstocks to create a portfolio of viable markets 
enabled by a plethora of technology and market specifications. Cooperation is supported and direct competition among the ecosystems' members is low to create shared value.

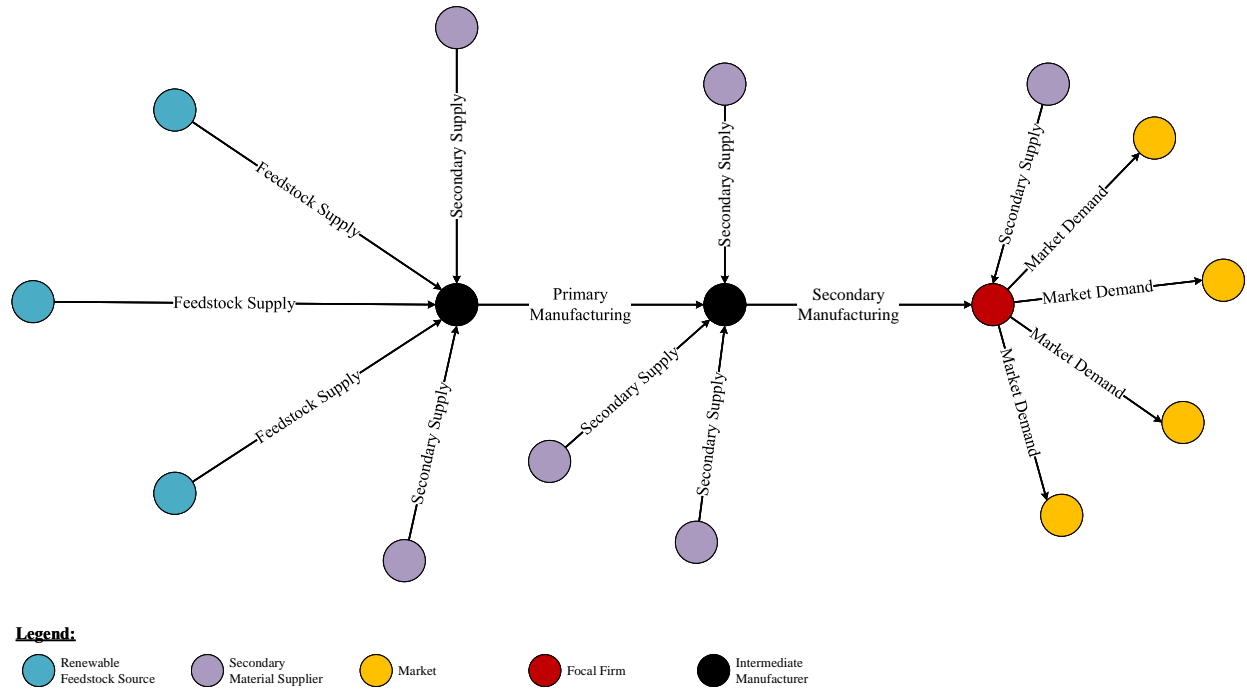

Figure 4 Circular supply network archetypes - Decentralised configuration.

\section{Conclusions}

This research sets out the theorisation of basic circular supply network configuration archetypes for the valorisation of solid waste feedstocks into commercially viable propositions. In particular, literature findings indicate that the greatest potential for the realisation of commercially viable circular networks stems from the following wasted material: (i) glass; (ii) metals and alloys; (iii) paper and cardboard; (iv) plastics and rubber; (v) wood; and (vi) organic waste. In an attempt to answer the Research Question of this study, we critically analysed our literature review findings to exemplify the three identified circular supply network configuration archetypes emerging from solid waste renewable feedstocks, namely: (i) centralised; (ii) semi-centralised; and (iii) decentralised. Our analysis suggests that the different wasted material require either local (e.g. wood, organic waste), regional (e.g. glass, plastics and rubber, paper and cardboard) or pan-regional (e.g. metals and alloys) network configuration options that can inform investment strategies and environmental policy initiatives. Table 7 summarises key attributes of the three identified circular supply chain configuration archetypes.

Table 7 Circular supply chain archetypes and network configuration attributes.

\begin{tabular}{lllll}
\hline \multirow{2}{*}{ Attribute } & \multicolumn{3}{c}{ Circular Supply Chain Archetype } \\
& Centralised & Semi-centralised & Decentralised \\
\hline $1 . \quad$ Feedstock homogeneity & Requires & Requires & Accommodated \\
& homogeneity & homogeneity & $\begin{array}{l}\text { by segregation } \\
\text { and sorting }\end{array}$
\end{tabular}
2. Economies of scale
Enabler
Enabler
Inhibiter 
Supply network configuration archetypes for the circular exploitation of solid

waste

3. Investments' requirement

High

High

Low

4. Risk mitigation

High

High

Low

capabilities

5. Transportation costs

High

Medium

Low

6. Recommended renewable feedstock

$\begin{array}{ccc}\text { Glass; Metals and } & \text { Paper and } & \text { Organic waste } \\ \text { alloys; Paper and } & \text { cardboard; } & \\ \text { cardboard; } & \text { Wood; Organic } & \\ \text { Plastics and } & \text { waste } \\ \text { rubber; Wood } & \end{array}$

\subsection{Theoretical implications}

The identification and selection of sustainable circular supply network archetypes within the resource-efficient economy context is characterised as a "wicked" issue sensu Stahl and Cimorelli (2013), often approached from a merely mono-variate perspective (Zijp et al., 2016) and neglecting the involvement of multiple disciplines and stakeholders across the value chain. This study is a first step towards articulating circular network archetypes based on the type of the available renewable feedstock. Linking renewable input materials to networks' structural archetypes advances Operations Management theory in circular supply networks as managers are informed about the generative network configuration dynamics (Boyer et al., 2000). In addition, our critical analysis suggests that circular supply chain planners should ensure that any manufacturing processes and transformative operations of the elaborated wasted feedstocks into value-added production inputs do not offset any expected environmental or economic benefits (Castellani et al. 2017).

Our study first identifies major solid waste feedstocks that can effectively replace natural and petrochemical-based raw materials in engineering applications. The valorisation of solid wastes to alternative raw materials associates to several advantages, compared to the use of primary natural resources, including resource preservation of natural raw materials, reduced cost owing to the lower energy consumption during processing, and improvement in human health and safety due to lower pollutant emission levels. The dominant economic segment that applies such renewable feedstocks is the construction industry, mainly in fabricating novel structural and insulation building solutions. The exploitation of discarded feedstocks in the sector is mainly driven by cost control considerations while any environmental regulations further motivate the use of "green materials" containing high amount of post-consumer waste, like for example the LEED Certification (Leadership in Energy and Environmental Design) in buildings (U.S. Green Building Council, 2019). To that end, the exploitation of wasted feedstocks should be encouraged through an amalgam of standardisation, legislation and financial incentives. Furthermore, the scientific community should explore novel research avenues for many wasted materials while public and business stakeholders need to raise trust over the demonstrated research outputs. 


\subsection{Practical implications}

Our research highlights, but not exhaustively investigates, several salient points that industry stakeholders and operations managers need to consider during the design phase of a circular supply network, including: (i) renewable feedstocks pre-processing options to control their physical or chemical characteristics in order to enhance the performance of the resulting intermediate or end-product; (ii) material-based laboratory experiments to navigate the optimum replacement ratio of renewable feedstocks to the hosting material depending on the desired electro-mechanical properties of the final commercial offering; (iii) possible by-products to establish additional commercial opportunities; (iv) financing options; and (v) effective conversations and interactions among business stakeholders. Thereafter, system factors like culture, economic development, climate, and energy sources influence the composition of the collected renewable feedstocks and could inform the selected circular supply network configuration archetype.

Despite any shortcomings, the configuration archetypes identified in this study could offer managerial insights to stakeholders to develop constellations of supply networks and renewable feedstocks to tackle challenges and harness opportunities arising within a circular economy context. However, in several cases the strategic preference on the network archetype is dictated by the prevalent policies in a regional context (Govindan and Hasanagic, 2018), like the debate about the upgrading of the decentralised biogas digesters' supply system in China towards a centralised paradigm with a range of socioeconomic ramifications (Chen and Liu, 2017). In any case, the selection of the feedstocknetwork archetype nexus should not be the goal but be the initial stage of circular supply chain operations planning to strengthen an organization's core processes.

\subsection{Limitations}

In conducting this study, some limitations are evident which, however, provide interesting grounds for expanding our research horizons. Firstly, the provided analysis was based on a critical synthesis of the extant literature review. Primary industry inputs and evidence could provide greater insights into the feedstock characteristics that lead the circular supply network configurational archetype and would facilitate validation and generalisability of the provided findings. Secondly, as this is an on-going study, it is positioned at a conceptual level, but does not quantify quality, cost, lead time and inventory management considerations resulting from specific feedstocks.

\subsection{Future research}

We envisage that the presented key network configuration archetypes, along with the respective synthesis of renewable feedstocks, could provide a guiding systemic framework for researchers and practitioners alike in their evolving efforts towards the efficient design and management of circular supply networks. As such, this research proposes a simple model that could assist stakeholders in making an abstract, yet realistic, analysis of renewable feedstocks to transit towards a circular economy business model. Nevertheless, the impact of advanced manufacturing technology options (Tziantopoulos et al., 2019) along with profitability parameters that influence the 
Supply network configuration archetypes for the circular exploitation of solid

waste

resulting configuration archetype should be investigated to make more informed strategic management decisions (van Loon et al., 2018).

\section{Acknowledgements}

We are indebted to the two anonymous referees and SI Editor, Prof. Benny Tjahjono, for their comments and suggestions that helped improve the context and the presentation of the material in the paper. This research has received funding from the EPSRC Reference No. EP/K014889/1 - "Terpene-based Manufacturing for Sustainable Chemical Feedstocks", and the EPSRC Reference No. EP/K02888X/1 - "Engineering Driven Sustainable Supply Networks - A UK/India Collaborative Study”.

\section{References}

Abd-Alla, M.H., Zohri, A.-N.A., El-Enany, A.-W.E. and Ali, S.M. (2017) 'Conversion of food processing wastes to biofuel using clostridia', Anaerobe, Vol. 48, pp.135-143.

Abdel-Shafy, H.I. and Mansour, M.S.M. (2018) 'Solid waste issue: Sources, composition, disposal, recycling, and valorization', Egyptian Journal of Petroleum, Vol. 27, pp.1275-1290.

Ahmadi, M., Farzin, S., Hassani, A. and Motamedi, M. (2017) 'Mechanical properties of the concrete containing recycled fibers and aggregates', Construction and Building Materials, Vol. 144, pp.392-398.

Al-Jabri, K.S., Hisada, M., Al-Oraimi, S.K. and Al-Saidy, A.H. (2009) 'Copper slag as sand replacement for high performance concrete', Cement and Concrete Composites, Vol. 31 No. 7, pp.483-488.

Al-Tulaian, B.S., Al-Shannag, M.J. and Al-Hozaimy, A.R. (2016) 'Recycled plastic waste fibers for reinforcing Portland cement mortar', Construction and Building Materials, Vol. 127, pp.102-110.

Aleluia, J. and Ferrão, P. (2017) 'Assessing the costs of municipal solid waste treatment technologies in developing Asian countries', Waste Management, Vol. 69, pp.592608.

Aliabdo, A.A., Abd Elmoaty, A.E.M. and Aboshama, A.Y. (2016) 'Utilization of waste glass powder in the production of cement and concrete', Construction and Building Materials, Vol. 124, pp.866-877.

Ambily, P.S., Umarani, C., Ravisankar, K., Prem, P.R., Bharatkumar, B.H. and Iyer, N.R. (2015) 'Studies on ultra high performance concrete incorporating copper slag as fine aggregate', Construction and Building Materials, Vol. 77, pp.233-240.

Andreola, F., Barbieri, L., Lancellotti, I., Leonelli, C. and Manfredini, T. (2016) 'Recycling of industrial wastes in ceramic manufacturing: State of art and glass case studies', Ceramics International, Vol. 42 No. 12, pp.13333-13338.

Argun, H. and Onaran, G. (2016) 'Hydrogen gas production from waste paper by sequential dark fermentation and electrohydrolysis', International Journal of Hydrogen Energy, Vol. 41 No. 19, pp.8057-8066. 
Avila-López, U., Almanza-Robles, J.M. and Escalante-García, J.I. (2015) 'Investigation of novel waste glass and limestone binders using statistical methods', Construction and Building Materials, Vol. 82, pp.296-303.

Ayanoğlu, A. and Yumrutaş, R. (2016) 'Production of gasoline and diesel like fuels from waste tire oil by using catalytic pyrolysis', Energy, Vol. 103, pp.456-468.

Aydin, H. and Ilkiliç, C. (2015) 'Analysis of combustion, performance and emission characteristics of a diesel engine using low sulfur tire fuel', Fuel, Vol. 143, pp.373382.

Ban, C.C. and Ramli, M. (2011) 'The implementation of wood waste ash as a partial cement replacement material in the production of structural grade concrete and mortar: An overview', Resources, Conservation and Recycling, Vol. 55 No. 7, pp.669-685.

Batista, L., Bourlakis, M., Smart, P. and Maull, R. (2018) 'In search of a circular supply chain archetype - a content-analysis-based literature review', Production Planning and Control: The Management of Operations, Vol. 29, pp.438-451.

Bergeron, F.C. (2016) 'Energy and climate impact assessment of waste wood recovery in Switzerland', Biomass and Bioenergy, Vol. 94, pp.245-257.

Bhogayata, A.C. and Arora, N.K. (2017) 'Fresh and strength properties of concrete reinforced with metalized plastic waste fibers', Construction and Building Materials, Vol. 146, pp.455-463.

Boyer, K.K., Bozarth, C. and McDermott, C. (2000) 'Configurations in operations: An emerging area of study', Journal of Operations Management, Vol. 18 No. 6, pp.601604.

Brummer, V, Jurena, T., Hlavacek, V., Omelkova, J., Bebar, L., Gabriel, P. and Stehlik, P. (2014) 'Enzymatic hydrolysis of pretreated waste paper - Source of raw material for production of liquid biofuels', Bioresource Technology, Vol. 152, pp.543-547.

Bulut, H.A. and Şahin, R. (2017) 'A study on mechanical properties of polymer concrete containing electronic plastic waste', Composite Structures, Vol. 178, pp.50-62.

Buttermann, G., Germain, R. and Iyer, K.N.S. (2008), 'Contingency theory "fit" as gestalt: An application to supply chain management', Transportation Research Part E: Logistics and Transportation Review, Vol. 44 No. 6, pp.955-969.

Carlini, R., Alfieri, I., Zanicchi, G., Soggia, F., Gombia, E. and Lorenzi, A. (2016) 'Synthesis and characterization of iron-rich glass ceramic materials: A model for steel industry waste reuse', Journal of Materials Science and Technology, Vol. 32 No. 11, pp.1105-1110.

Castellani, V., Sala, S. and Benini, L. (2017) 'Hotspots analysis and critical interpretation of food life cycle assessment studies for selecting eco-innovation options and for policy support', Journal of Cleaner Production, Vol. 140, pp.556-568.

Cesário, M.T., Raposo, R.S., de Almeida, M.C.M.D., van Keulen, F., Ferreira, B.S. and da Fonseca, M.M.R. (2014) 'Enhanced bioproduction of poly-3-hydroxybutyrate from wheat straw lignocellulosic hydrolysates', New Biotechnology, Vol. 31 No. 1, pp.104113.

Chen, Q. and Liu, T. (2017) 'Biogas system in rural China: Upgrading from decentralized to centralized?', Renewable and Sustainable Energy Reviews, Vol. 78, pp.933-944.

Chiang, P.-N., Tong, O.-Y., Chiou, C.-S., Lin, Y.-A., Wang, M.-K. and Liu, C.-C. (2016) 'Reclamation of zinc-contaminated soil using a dissolved organic carbon solution 
Supply network configuration archetypes for the circular exploitation of solid

waste

prepared using liquid fertilizer from food-waste composting', Journal of Hazardous Materials, Vol. 301, pp.100-105.

Choi, S.Y., Choi, Y.S. and Yang, E.I. (2017) 'Effects of heavy weight waste glass recycled as fine aggregate on the mechanical properties of mortar specimens', Annals of Nuclear Energy, Vol. 99, pp.372-382.

Collins, T. and Kuehr, R. (2015). Discarded kitchen, laundry, bathroom equipment comprises over half of world e-waste: UNU Report. [online] United Nations University, Tokyo. http://i.unu.edu/media/unu.edu/news/52624/Discarded-KitchenLaundry-Bathroom-Equipment-Comprises-Over-Half-of-World-E-waste.pdf (Accessed 10 August 2017).

Cucina, M., Tacconi, C., Ricci, A., Pezzolla, D., Sordi, S., Zadra, C. and Gigliotti, G. (2018) 'Evaluation of benefits and risks associated with the agricultural use of organic wastes of pharmaceutical origin', Science of The Total Environment, Vol. 613-614, pp.773-782.

D'Amore, G.K.O., Caniato, M., Travan, A., Turco, G., Marsich, L., Ferluga, A. and Schmid, C. (2017) 'Innovative thermal and acoustic insulation foam from recycled waste glass powder', Journal of Cleaner Production, Vol. 165, pp.1306-1315.

da Silva, F.L., Araújo, F.G.S., Teixeira, M.P., Gomes, R.C. and von Krüger, F.L. (2014) 'Study of the recovery and recycling of tailings from the concentration of iron ore for the production of ceramic', Ceramics International, Vol. 40 No. 10, pp.16085-16089.

Dahiya, S., Kumar, A.N., Sravan, J.S., Chatterjee, S., Sarkar, O. and Mohan, S.V. (2018) 'Food waste biorefinery: Sustainable strategy for circular bioeconomy', Bioresource Technology, Vol. 248 Part A, pp.2-12.

Das, S., Lee, S.-H., Kumar, P., Kim, K.-H., Lee, S.S. and Bhattacharya, S.S. (2019) 'Solid waste management: Scope and the challenge of sustainability', Journal of Cleaner Production, Vol. 228, pp.658-678.

Davis, R., Kataria, R., Cerrone, F., Woods, T., Kenny, S., O’Donovan, A., Guzik, M., Shaikh, H., Duane, G., Gupta, V.K., Tuohy, M.G., Padamatti, R.B., Casey, E. and O'Connor, K.E. (2013) 'Conversion of grass biomass into fermentable sugars and its utilization for medium chain length polyhydroxyalkanoate (mcl-PHA) production by Pseudomonas strains', Bioresource Technology, Vol. 150, pp.202-209.

Dehghanian, F. and Mansour, S. (2009) 'Designing sustainable recovery network of endof-life products using genetic algorithm', Resources, Conservation and Recycling, Vol. 53 No. 10, pp.559-570.

Dobrotă, D. and Dobrotă, G. (2017) 'An innovative method in the regeneration of waste rubber and the sustainable development', Journal of Cleaner Production, Vol. 172, pp.3591-3599.

Domski, J., Katzer, J., Zakrzewski, M. and Ponikiewski, T. (2017) 'Comparison of the mechanical characteristics of engineered and waste steel fiber used as reinforcement for concrete', Journal of Cleaner Production, Vol. 158, pp.18-28.

dos Anjos, M.A.G., Sales, A.T.C. and Andrade, N. (2017) 'Blasted copper slag as fine aggregate in Portland cement concrete', Journal of Environmental Management, Vol. 196, pp.607-613.

El-Naggar, M.R. and El-Dessouky, M.I. (2017) 'Re-use of waste glass in improving properties of metakaolin-based geopolymers: Mechanical and microstructure examinations', Construction and Building Materials, Vol. 132, pp.543-555. 
Elinwa, A.U. and Mahmood, Y.A. (2002) 'Ash from timber waste as cement replacement material', Cement and Concrete Composites, Vol. 24 No. 2, pp.219-222.

Ellen MacArthur Foundation (2015) Growth within: A circular economy vision for a competitive Europe. [online] Report, Ellen MacArthur Foundation, Stiftungsfonds für Umweltökonomie und Nachhaltigkeit (SUN) and McKinsey Centre for Business and Environment.

https://www.ellenmacarthurfoundation.org/assets/downloads/publications/EllenMacA rthurFoundation_Growth-Within_July15.pdf (Accessed 21 June 2017)

Elliston, A., Collins, S.R.A., Wilson, D.R., Roberts, I.N. and Waldron, K.W. (2013) 'High concentrations of cellulosic ethanol achieved by fed batch semi simultaneous saccharification and fermentation of waste-paper', Bioresource Technology, Vol. 134, pp.117-126.

EPA (2016) Advancing sustainable materials management: 2014 Tables and figures Assessing trends in material generation, recycling, composting, combustion with energy recovery and landfilling in the United States. [online] United States Environmental Protection Agency, Washington DC. https://www.epa.gov/sites/production/files/2016-

11/documents/2014_smm_tablesfigures_508.pdf (Accessed 05 June 2017)

Erfani, S.M.H., Danesh, S., Karrabi, S.M., Shad, R. and Nemati, S. (2018) 'Using applied operations research and geographical information systems to evaluate effective factors in storage service of municipal solid waste management systems', Waste Management, Vol. 79, pp.346-355.

Eurostat (2019) Generation of waste by waste category, hazardousness and NACE Rev. 2 activity. [online] Statistics database, European Commission, Products Datasets. https://ec.europa.eu/eurostat/en/web/products-datasets/-/ENV_WASGEN (Accessed 14 March 2019)

Ewais, E.M.M., Besisa, N.H.A. and Ahmed, A. (2017) 'Aluminum titanate based ceramics from aluminum sludge waste', Ceramics International, Vol. 43 No. 13, pp.10277-10287.

Ewais, E.M.M., Khalil, N.M., Amin, M.S., Ahmed, Y.M.Z. and Barakat, M.A. (2009) 'Utilization of aluminum sludge and aluminum slag (dross) for the manufacture of calcium aluminate cement', Ceramics International, Vol. 35 No. 8, pp.3381-3388.

FAO (2011) Global food losses and food waste: Extent, causes and prevention. [online] Food and Agriculture Organization of the United Nations, Rome. http://www.fao.org/docrep/014/mb060e/mb060e00.pdf (Accessed 10 October 2017).

Farzana, R., Rajarao, R. and Sahajwalla, V. (2014) 'Synthesis of ferrosilicon alloy using waste glass and plastic', Materials Letters, Vol. 116, pp.101-103.

Farzana, R., Rajarao, R. and Sahajwalla, V. (2016) 'Characteristics of waste automotive glasses as silica resource in ferrosilicon synthesis', Waste Management and Research, Vol. 34 No. 2, pp.113-121.

Frost \& Sullivan (2016) GCC waste management industry to present untapped opportunities, notes Frost \& Sullivan. [online] Frost \& Sullivan, California. https://ww2.frost.com/news/press-releases/gcc-waste-management-industry-presentuntapped-opportunities-notes-frost-sullivan/ (Accessed 20 June 2017)

Galán-Arboledas, R.J., de Diego, J.Á., Dondi, M. and Bueno, S. (2017) 'Energy, environmental and technical assessment for the incorporation of EAF stainless steel 
Supply network configuration archetypes for the circular exploitation of solid

waste

slag in ceramic building materials', Journal of Cleaner Production, Vol. 142, pp.1778-1788.

Garcia, C.A. and Hora, G. (2017) 'State-of-the-art of waste wood supply chain in Germany and selected European countries', Waste Management, Vol. 70, pp.189-197.

Genovese, A., Acquaye, A.A., Figueroa, A. and Koh, L.S.C. (2017), 'Sustainable supply chain management and the transition towards a circular economy: Evidence and some applications', Omega, Vol. 66 Part B, pp.344-357.

Geunes, J., Romeijn, H.E. and van den Heuvel, W. (2016) 'Improving the efficiency of decentralized supply chains with fixed ordering costs', European Journal of Operational Research, Vol. 252 No. 3, pp.815-828.

Ghannam, S., Najm, H. and Vasconez, R. (2016) 'Experimental study of concrete made with granite and iron powders as partial replacement of sand', Sustainable Materials and Technologies, Vol. 9, pp.1-9.

Ghouleh, Z., Guthrie, R.I.L. and Shao, Y. (2017) 'Production of carbonate aggregates using steel slag and carbon dioxide for carbon-negative concrete', Journal of CO2 Utilization, Vol. 18, pp.125-138.

Gil, A. and Korili, S.A. (2016) 'Management and valorization of aluminum saline slags: Current status and future trends', Chemical Engineering Journal, Vol. 289, pp.74-84.

Girskas, G. and Nagrockienè, D. (2017) 'Crushed rubber waste impact of concrete basic properties’, Construction and Building Materials, Vol. 140, pp.36-42.

Govindan, K. and Hasanagic, M. (2018) 'A systematic review on drivers, barriers, and practices towards circular economy: A supply chain perspective', International Journal of Production Research, Vol. 56 No. 1-2, pp.278-311.

Greenwood, R. and Hinings, C.R. (1993) 'Understanding strategic change: The contribution of archetypes', Academy of Management Journal, Vol. 36 No. 5, pp.1052-1081.

Gu, F., Ma, B., Guo, J., Summers, P.A. and Hall, P. (2017) 'Internet of things and Big Data as potential solutions to the problems in waste electrical and electronic equipment management: An exploratory study', Waste Management, Vol. 68, pp.434448.

Gutierrez, A., Miró, L., Gil, A., Rodríguez-Aseguinolaza, J., Barreneche, C., Calvet, N., Py, X., Fernández, A.I., Grágeda, M., Ushak, S. and Cabeza, L.F. (2016) ‘Advances in the valorization of waste and by-product materials as thermal energy storage (TES) materials', Renewable and Sustainable Energy Reviews, Vol. 59, pp.763-783.

Hama, S.M. and Hilal, N.N. (2017) 'Fresh properties of self-compacting concrete with plastic waste as partial replacement of sand', International Journal of Sustainable Built Environment, Vol. 6 No. 2, pp.299-308.

Hao, W. and Mi, Y. (2016) 'Evaluation of waste paper as a source of carbon fuel for hybrid direct carbon fuel cells', Energy, Vol. 107, pp.122-130.

He, F., Fang, Y., Xie, J. and Xie, J. (2012) 'Fabrication and characterization of glassceramics materials developed from steel slag waste', Materials and Design, Vol. 42, pp.198-203.

Hegde, S., Lodge, J.S. and Trabold, T.A. (2018) 'Characteristics of food processing wastes and their use in sustainable alcohol production', Renewable and Sustainable Energy Reviews, Vol. 81 Part 1, pp.510-523.

Hoornweg, D. and Bhada-Tata, P. (2012) What a waste: A global review of solid waste management. [online] Urban Development and Local Government Unit Knowledge 
N. Tsolakis et al.

Papers No.15, Sustainable Development Network, The World Bank, Washington DC. https://siteresources.worldbank.org/INTURBANDEVELOPMENT/Resources/336387 -1334852610766/What_a_Waste2012_Final.pdf (Accessed 07 June 2017)

Huaiwei, Z. and Xin, H. (2011) 'An overview for the utilization of wastes from stainless steel industries', Resources, Conservation and Recycling, Vol. 55 No. 8, pp.745-754.

Iiu, J., Meng, J., Liang, J., Duan, X., Huo, X. and Tang, Q. (2015) 'Effect of rare earth Ce on the far infrared radiation property of iron ore tailings ceramics', Materials Research Bulletin, Vol. 66, pp.26-31.

International Aluminium Institute (2009) Global aluminium recycling: A cornerstone of sustainable development. [online] International Aluminium Institute, London. http://www.world-aluminium.org/media/filer_public/2013/01/15/f10000181.pdf (Accessed 22 September 2017).

Ismail, Z.Z. and AL-Hashmi, E.A. (2009) 'Recycling of waste glass as a partial replacement for fine aggregate in concrete', Waste Management, Vol. 29 No. 2, pp.655-659.

ISSF, 2016. Stainless steel in figures 2016. [online] International Stainless Steel Forum, Brussels. https://aceroplatea.es/docs/StainlessSteelFigures2016.pdf (Accessed 14 March 2019).

Jimenez, J., Lei, H., Steyer, J.-P., Houot, S. and Patureau, D. (2017) 'Methane production and fertilizing value of organic waste: Organic matter characterization for a better prediction of valorization pathways', Bioresource Technology, Vol. 241, pp.10121021.

Joshi, G., Naithani, S., Varshney, V.K., Bisht, S.S. and Rana, V. (2017) 'Potential use of waste paper for the synthesis of cyanoethyl cellulose: A cleaner production approach towards sustainable environment management', Journal of Cleaner Production, Vol. 142 Part 4, pp.3759-3768.

Kao, T.-W., Simpson, N.C., Shao, B.B.M. and Lin, W.T. (2017) 'Relating supply network structure to productive efficiency: A multi-stage empirical investigation', European Journal of Operational Research, Vol. 259 No. 2, pp.469-485.

Karmee, S.K. (2016) 'Liquid biofuels from food waste: Current trends, prospect and limitation', Renewable and Sustainable Energy Reviews, Vol. 53, pp.945-953.

Khorami, M., Ganjian, E., Mortazavi, A., Saidani, M., Olubanwo, A. and Gand, A. (2017) 'Utilisation of waste cardboard and Nano silica fume in the production of fibre cement board reinforced by glass fibres', Construction and Building Materials, Vol. 152, pp.746-755.

Kim, K., Kim, K. and Hwang, J. (2016) 'Characterization of ceramic tiles containing LCD waste glass', Ceramics International, Vol. 42 No. 6, pp.7626-7631.

Kim, Y., Chen, Y.-S. and Linderman, K. (2015) 'Supply network disruption and resilience: A network structural perspective', Journal of Operations Management, Vol. 33-34, pp.43-59.

Koolivand, A., Mazandaranizadeh, H., Binavapoor, M., Mohammadtaheri, A. and Saeedi, R. (2017) 'Hazardous and industrial waste composition and associated management activities in Caspian industrial park, Iran', Environmental Nanotechnology, Monitoring and Management, Vol. 7, pp.9-14.

Lee, W.S., Chua, A.S.M., Yeoh, H.K. and Ngoh, G.C. (2014) 'A review of the production and applications of waste-derived volatile fatty acids', Chemical Engineering Journal, Vol. 235, pp.83-99. 
Supply network configuration archetypes for the circular exploitation of solid

waste

Lessing, J., Glavan, A.C., Walker, S.B., Keplinger, C., Lewis, J.A. and Whitesides, G.M. (2014) 'Inkjet printing of conductive inks with high lateral resolution on omniphobic "RF Paper" for paper-based electronics and MEMS', Advanced Materials, Vol. 26 No. 27, pp.4677-4682.

Liao, X., Liao, Q., Yan, X., Liang, Q., Si, H., Li, M., Wu, H., Cao, S. and Zhang, Y. (2015) 'Flexible and highly sensitive strain sensors fabricated by pencil drawn for wearable monitor', Advanced Functional Materials, Vol. 25 No. 16, pp.2395-2401.

Liao, X., Zhang, Z., Liao, Q., Liang, Q., Ou, Y., Xu, M., Li, M., Zhang, G. and Zhang, Y. (2016) 'Flexible and printable paper-based strain sensors for wearable and large-area green electronics', Nanoscale, Vol. 8 No. 26, pp.13025-13032.

Liu, F. and Song, J.-S. (2017) 'Coordinating a semi-centralized global production network through different levels of headquarters involvement', Production and Operations Management, Vol. 26 No. 2, pp.305-319.

Liu, H., Qing, H., Li, Z., Han, Y.L., Lin, M., Yang, H., Li, A., Lu, T.J., Li, F. and Xu, F. (2017) 'Paper: A promising material for human-friendly functional wearable electronics', Materials Science and Engineering: R: Reports, Vol. 112, pp.1-22.

Liu, Y., Leong, B.S., Hu, Z.-T. and Yang, E.-H. (2017) 'Autoclaved aerated concrete incorporating waste aluminum dust as foaming agent', Construction and Building Materials, Vol. 148, pp.140-147.

Lu, J.-X., Duan, Z.-H. and Poon, C.S. (2017) 'Combined use of waste glass powder and cullet in architectural mortar', Cement and Concrete Composites, Vol. 82, pp.34-44.

Lupton, S. (2017) 'Markets for waste and waste-derived fertilizers. An empirical survey', Journal of Rural Studies, Vol. 55, pp.83-99.

Magnaghi, G. (2014) Recovered paper market in 2012. [online] BIR Global Facts \& Figures, Brussels. http://www.bir.org/assets/Documents/publications/brochures/BIRPaperStats-2014-V3.pdf (Accessed 03 October 2017).

Marinoni, N., D'Alessio, D., Diella, V., Pavese, A. and Francescon, F. (2013) 'Effects of soda-lime-silica waste glass on mullite formation kinetics and micro-structures development in vitreous ceramics', Journal of Environmental Management, Vol. 124, pp.100-107.

Martínez-Lage, I., Velay-Lizancos, M., Vázquez-Burgo, P., Rivas-Fernández, M., Vázquez-Herrero, C., Ramírez-Rodríguez, A. and Martín-Cano, M. (2016) 'Concretes and mortars with waste paper industry: Biomass ash and dregs', Journal of Environmental Management, Vol. 181, pp.863-873.

Memon, S.A., Lo, T.Y. and Cui, H. (2013) 'Utilization of waste glass powder for latent heat storage application in buildings', Energy and Buildings, Vol. 66, pp.405-414.

Michaud, J.-C., Farrant, L. and Jan, O. (2010) Environmental benefits of recycling - 2010 update. [online] Water \& Resources Action Programme (WRAP), Banbury. http://www.wrap.org.uk/sites/files/wrap/Environmental_benefits_of_recycling_2010_ update.3b174d59.8816.pdf (Accessed 04 October 2017).

Mo, L., Zhang, F., Deng, M., Jin, F., Al-Tabbaa, A. and Wang, A. (2017) 'Accelerated carbonation and performance of concrete made with steel slag as binding materials and aggregates', Cement and Concrete Composites, Vol. 83, pp.138-145.

Mongeon, P. and Paul-Hus, A. (2016), 'The journal coverage of Web of Science and Scopus: A comparative analysis', Scientometrics, Vol. 106 No. 1, pp.213-228. 
Moqsud, M.A., Omine, K., Yasufuku, N., Hyodo, M. and Nakata, Y. (2013) 'Microbial fuel cell (MFC) for bioelectricity generation from organic wastes', Waste Management, Vol. 33 No. 11, pp.2465-2469.

Moutinho, V., Varum, C. and Madaleno, M. (2017) 'How economic growth affects emissions? An investigation of the environmental Kuznets curve in Portuguese and Spanish economic activity sectors', Energy Policy, Vol. 106, pp.326-344.

Munoz, L.E.A. and Riley, M.R. (2008) 'Utilization of cellulosic waste from tequila bagasse and production of polyhydroxyalkanoate (PHA) bioplastics by Saccharophagus degradans', Biotechnology and Bioengineering, Vol. 100 No. 5, pp.882-888.

Murayama, N., Maekawa, I., Ushiro, H., Miyoshi, T., Shibata, J. and Valix, M. (2012) 'Synthesis of various layered double hydroxides using aluminum dross generated in aluminum recycling process', International Journal of Mineral Processing, Vol. 110111, pp.46-52.

Musee, N., Lorenzen, L. and Aldrich, C. (2008) 'New methodology for hazardous waste classification using fuzzy set theory: Part I. Knowledge acquisition', Journal of Hazardous Materials, Vol. 154 No. 1-3, pp.1040-1051.

Mymrin, V., Alekseev, K., Catai, R.E., Nagalli, A., Aibuldinov, Y.K., Bekturganov, N.S., Rose, J.L. and Izzo, R.L.S. (2016) 'Red ceramics from composites of hazardous sludge with foundry sand, glass waste and acid neutralization salts', Journal of Environmental Chemical Engineering, Vol. 4 No. 1, pp.753-761.

Mymrin, V., Guidolin, M.A., Klitzke, W., Alekseev, K., Guidolin, R.H., Avanci, M.A., Pawlowsky, U., Winter Jr., E. and Catai, R.E. (2017) 'Environmentally clean ceramics from printed circuit board sludge, red mud of bauxite treatment and steel slag', Journal of Cleaner Production, Vol. 164, pp.831-839.

Nasir, M.H.A., Genovese, A., Acquaye, A.A., Koh, S.C.L. and Yamoah, F. (2017) 'Comparing linear and circular supply chains: A case study from the construction industry', International Journal of Production Economics, Vol. 183 Part B, pp.443457.

Neugebauer, M. and Sołowiej, P. (2017) 'The use of green waste to overcome the difficulty in small-scale composting of organic household waste', Journal of Cleaner Production, Vol. 156, pp.865-875.

Nishimura, H., Tan, L., Kira, N., Tomiyama, S., Yamada, K., Sun, Z.-Y., Tang, Y.-Q., Morimura, S. and Kida, K. (2017) 'Production of ethanol from a mixture of waste paper and kitchen waste via a process of successive liquefaction, presaccharification, and simultaneous saccharification and fermentation', Waste Management, Vol. 67, pp.86-94.

Nizami, A.S., Rehan, M., Waqas, M., Naqvi, M., Ouda, O.K.M, Shahzad, K., Miandad, R., Khan, M.Z., Syamsiro, M., Ismail, I.M.I. and Pant, D. (2017) 'Waste biorefineries: Enabling circular economies in developing countries', Bioresource Technology, Vol. 241, pp.1101-1117.

Novais, R.M., Ascensão, G., Seabra, M.P. and Labrincha, J.A. (2016) 'Waste glass from end-of-life fluorescent lamps as raw material in geopolymers', Waste Management, Vol. 52, pp.245-255.

Novais, R.M., Seabra, M.P. and Labrincha, J.A. (2015) 'Wood waste incorporation for lightweight porcelain stoneware tiles with tailored thermal conductivity', Journal of Cleaner Production, Vol. 90, pp.66-72. 
Supply network configuration archetypes for the circular exploitation of solid

waste

Parajuli, R., Knudsen, M.T. and Dalgaard, T. (2015) 'Multi-criteria assessment of yellow, green, and woody biomasses: Pre-screening of potential biomasses as feedstocks for biorefineries', Biofuels, Bioproducts and Biorefining, Vol. 9 No. 5, pp.545-566.

Parajuli, R., Knudsen, M.T., Djomo, S.N., Corona, A., Birkved, M. and Dalgaard, T. (2017) 'Environmental life cycle assessment of producing willow, alfalfa and straw from spring barley as feedstocks for bioenergy or biorefinery systems', Science of The Total Environment, Vol. 586, pp.226-240.

Pasupuleti, S.B., Sarkar, O. and Mohan, S.V. (2014) 'Upscaling of biohydrogen production process in semi-pilot scale biofilm reactor: Evaluation with food waste at variable organic loads', International Journal of Hydrogen Energy, Vol. 39 No. 14, pp.7587-7596.

Pathak, S.D., Wu, Z. and Johnston, D. (2014) 'Toward a structural view of co-opetition in supply networks', Journal of Operations Management, Vol. 32 No. 5, pp.254-267.

Pivnenko, K., Olsson, M.E., Götze, R., Eriksson, E. and Astrup, T.F. (2016) 'Quantification of chemical contaminants in the paper and board fractions of municipal solid waste', Waste Management, Vol. 51, pp.43-54.

Poulikakos, L.D., Papadaskalopoulou, C., Hofko, B., Gschösser, F., Falchetto, A.C., Bueno, M., Arraigada, M., Sousa, J., Ruiz, R., Petit, C., Loizidou, M. and Partl, M.N. (2017) 'Harvesting the unexplored potential of European waste materials for road construction', Resources, Conservation and Recycling, Vol. 116, pp.32-44.

Rajput, D., Bhagade, S.S., Raut, S.P., Ralegaonkar, R.V. and Mandavgane, S.A. (2012) 'Reuse of cotton and recycle paper mill waste as building material', Construction and Building Materials, Vol. 34, pp.470-475.

Ramos, T., Matos, A.M. and Sousa-Coutinho, J. (2013) 'Mortar with wood waste ash: Mechanical strength carbonation resistance and ASR expansion', Construction and Building Materials, Vol. 49, pp.343-351.

Ravindran, R. and Jaiswal, A.K. (2016) 'Exploitation of food industry waste for highvalue products', Trends in Biotechnology, Vol. 34 No. 1, pp.58-69.

Reddy, M.S. and Neeraja, D. (2016) 'Mechanical and durability aspects of concrete incorporating secondary aluminium slag', Resource-Efficient Technologies, Vol. 2 No. 4, pp.225-232.

Rodriguez, C., Alaswad, A., El-Hassan, Z. and Olabi, A.G. (2017) 'Mechanical pretreatment of waste paper for biogas production', Waste Management, Vol. 68, pp.157-164.

Sadef, Y., Nizami, A.S., Batool, S.A., Chaudhary, M.N., Ouda, O.K.M., Asam, Z.Z., Habib, K., Rehan, M. and Demibras, A. (2016) 'Waste-to-energy and recycling value for developing integrated solid waste management plan in Lahore', Energy Sources, Part B: Economics, Planning, and Policy, Vol. 11 No. 7, pp.569-579.

Sadiqul Islam, G.M., Rahman, M.H. and Kazi, N. (2016) 'Waste glass powder as partial replacement of cement for sustainable concrete practice', International Journal of Sustainable Built Environment, Vol. 6 No. 1, pp.37-44.

Saikia, N. and de Brito, J. (2012) 'Use of plastic waste as aggregate in cement mortar and concrete preparation: A review', Construction and Building Materials, Vol. 34, pp.385-401.

Sengul, O. (2016) 'Mechanical behavior of concretes containing waste steel fibers recovered from scrap tires', Construction and Building Materials, Vol. 122, pp.649658. 
Sharma, R. and Khan, R.A. (2017) 'Sustainable use of copper slag in self compacting concrete containing supplementary cementitious materials', Journal of Cleaner Production, Vol. 151, pp.179-192.

Sharuddin, S.D.A., Abnisa, F., Wan Daud, W.M.A. and Aroua, M.K. (2017) 'Energy recovery from pyrolysis of plastic waste: Study on non-recycled plastics (NRP) data as the real measure of plastic waste', Energy Conversion and Management, Vol. 148, pp.925-934.

Shettima, A.U., Hussin, M.W., Ahmad, Y. and Mirza, J. (2016) 'Evaluation of iron ore tailings as replacement for fine aggregate in concrete', Construction and Building Materials, Vol. 120, pp.72-79.

Shi, C., Meyer, C. and Behnood, A. (2008) 'Utilization of copper slag in cement and concrete', Resources, Conservation and Recycling, Vol. 52 No. 10, pp.1115-1120.

Sienkiewicz, M., Janik, H., Borzędowska-Labuda, K. and Kucińska-Lipka, J. (2017) 'Environmentally friendly polymer-rubber composites obtained from waste tyres: A review', Journal of Cleaner Production, Vol. 147, pp.560-571.

Simão, L., Jiusti, J., Lóh, N.J., Hotza, D., Raupp-Pereira, F., Labrincha, J.A. and Montedo, O.R.K. (2017) 'Waste-containing clinkers: Valorization of alternative mineral sources from pulp and paper mills', Process Safety and Environmental Protection, Vol. 109, pp.106-116.

Sindhu, R., Silviya, N., Binod, P. and Pandey, A. (2013) 'Pentose-rich hydrolysate from acid pretreated rice straw as a carbon source for the production of poly-3hydroxybutyrate', Biochemical Engineering Journal, Vol. 78, pp.67-72.

Singh, A. (2019) 'Managing the uncertainty problems of municipal solid waste disposal', Journal of Environmental Management, Vol. 240, pp.259-265.

Singh, G. and Siddique, R. (2016) 'Effect of iron slag as partial replacement of fine aggregates on the durability characteristics of self-compacting concrete', Construction and Building Materials, Vol. 128, pp.88-95.

Skovsgaard, L. and Jacobsen, H.K. (2017) 'Economies of scale in biogas production and the significance of flexible regulation', Energy Policy, Vol. 101, pp.77-89.

Srai, J.S. and Gregory, M. (2008) 'A supply network configuration perspective on international supply chain development', International Journal of Operations and Production Management, Vol. 28 No. 5, pp.386-411.

Srai, J.S., Tsolakis, N., Kumar, M. and Bam, W. (2018) 'Circular supply chains and renewable chemical feedstocks: A network configuration analysis framework', Production Planning and Control: The Management of Operations, Vol. 29 No. 6, pp.464-482.

Stahl, C. and Cimorelli, A. (2013) 'A demonstration of the necessity and feasibility of using a clumsy decision analytic approach on wicked environmental problems', Integrated Environmental Assessment and Management, Vol. 9 No. 1, pp.17-30.

Su, H., Zhu, P., Zhang, L., Zhou, F., Li, G., Li, T., Wang, Q., Sun, R. and Wong, C. (2017) 'Waste to wealth: A sustainable and flexible supercapacitor based on office waste paper electrodes', Journal of Electroanalytical Chemistry, Vol. 786, pp.28-34.

Sua-iam, G. and Makul, N. (2017) 'Incorporation of high-volume fly ash waste and highvolume recycled alumina waste in the production of self-consolidating concrete', Journal of Cleaner Production, Vol. 159, pp.194-206. 
Supply network configuration archetypes for the circular exploitation of solid

waste

Sun, B., Yu, H.-Y., Zhou, Y., Huang, Z. and Yao, J.-M. (2016) 'Single-step extraction of functionalized cellulose nanocrystal and polyvinyl chloride from industrial wallpaper wastes', Industrial Crops and Products, Vol. 89, pp.66-77.

Svanberg, M., Finnsgård, C., Flodén, J. and Lundgren, J. (2018) 'Analyzing animal waste-to-energy supply chains: The case of horse manure', Renewable Energy, Vol. 129 Part B, pp.830-837.

Tansel, B. (2017) 'From electronic consumer products to e-wastes: Global outlook, waste quantities, recycling challenges’ Environment International, Vol. 98, pp.35-45.

Tchakouté, H.K., Rüscher, C.H., Kong, S., Kamseu, E. and Leonelli, C. (2016) 'Geopolymer binders from metakaolin using sodium waterglass from waste glass and rice husk ash as alternative activators: A comparative study', Construction and Building Materials, Vol. 114, pp.276-289.

Teo, P.T., Anasyida, A.S., Basu, P. and Nurulakmal, M.S. (2014) 'Recycling of Malaysia's electric arc furnace (EAF) slag waste into heavy-duty green ceramic tile', Waste Management, Vol. 34 No. 12, pp.2697-2708.

Torres-Carrasco, M. and Puertas, F. (2017) 'Waste glass as a precursor in alkaline activation: Chemical process and hydration products', Construction and Building Materials, Vol. 139, pp.342-354.

Tranfield, D., Denyer, D. and Smart, P. (2003), 'Towards a methodology for developing evidence-informed management knowledge by means of systematic review', British Journal of Management, Vol. 14 No. 3, pp.207-222.

Tsolakis, N. and Srai, J.S. (2017) 'Inventory planning and control in 'green' pharmacies supply chains - A System Dynamics modelling perspective', Computer Aided Chemical Engineering, Vol. 40, pp.1285-1290.

Tsolakis, N., Bam, W., Srai, J.S. and Kumar, M. (2019) 'Renewable chemical feedstock supply network design: The case of terpenes', Journal of Cleaner Production, Vol. 222, pp.802-822.

Tsolakis, N., Kumar, M. and Srai, J.S. (2016) 'Exploring opportunities for circular supply chains arising from renewable chemical feedstocks' in Keynote Papers of the OR58: The OR Society Annual Conference, Portsmouth University, Portsmouth, United Kingdom, pp.157-171.

Tziantopoulos, K., Tsolakis, N., Vlachos, D. and Tsironis, L. (2019) "Supply chain reconfiguration opportunities arising from additive manufacturing technologies in the digital era", Production Planning and Control: The Management of Operations, Vol. 30, pp.510-521.

U.S. Geological Survey (2018) Mineral commodity summaries: Aluminum. [online] National Minerals Information Center, United States Geological Survey, Virginia. https://minerals.usgs.gov/minerals/pubs/commodity/aluminum/mcs-2018-alumi.pdf (Accessed 14 March 2019).

U.S. Green Building Council (2019) LEED: Better buildings are our legacy. [online] U.S. Green Building Council, Atlanta, Illinois. https://new.usgbc.org/leed (Accessed 15 March 2019).

United Nations (2014) World urbanization prospects: The 2014 revision highlights. [online] Report ST/ESA/SER.A/352, Department of Economic and Social Affairs, The United Nations, New York. https://esa.un.org/unpd/wup/publications/files/wup2014-highlights.Pdf (Accessed 07 June 2017) 
Vafaei, M. and Allahverdi, A. (2017) 'High strength geopolymer binder based on wasteglass powder', Advanced Powder Technology, Vol. 28 No. 1, pp.215-222.

van Loon, P., Delagarde, C. and Van Wassenhove, L.N. (2018) 'The role of second-hand markets in circular business: A simple model for leasing versus selling consumer products', International Journal of Production Research, Vol. 56 No. 1-2, pp.960973.

Van-Thuoc, D., Quillaguamán, J., Mamo, G. and Mattiasson, B. (2008) 'Utilization of agricultural residues for poly(3-hydroxybutyrate) production by Halomonas boliviensis LC1', Journal of Applied Microbiology, Vol. 104 No. 2, pp.420-428.

Wang, C.-1., Ni, W., Zhang, S., Wang, S., Gai, G. and Wang, W. (2016) 'Preparation and properties of autoclaved aerated concrete using coal gangue and iron ore tailings', Construction and Building Materials, Vol. 104, pp.109-115.

Wang, L., Yu, I.K.M., Tsang, D.C.W., Li, S., Li, J., Poon, C.S., Wang, Y.-S. and Dai, J.G. (2017) 'Transforming wood waste into water-resistant magnesia-phosphate cement particleboard modified by alumina and red mud', Journal of Cleaner Production, Vol. 168, pp.452-462.

Wiemes, L., Pawlowsky, U. and Mymrin, V. (2017). 'Incorporation of industrial wastes as raw materials in brick's formulation', Journal of Cleaner Production, Vol. 142 Part 1, pp.69-77.

Wong, H.S., Barakat, R., Alhilali, A., Saleh, M. and Cheeseman, C.R. (2015) 'Hydrophobic concrete using waste paper sludge ash', Cement and Concrete Research, Vol. 70, pp.9-20.

Xing, K., Qian, W. and Zaman, A.U. (2016) 'Development of a cloud-based platform for footprint assessment in green supply chain management', Journal of Cleaner Production, Vol. 139, pp.191-203.

Xu, Z., Elomri, A., Pokharel, S., Zhang, Q., Ming, X.G. and Liu, W. (2017) 'Global reverse supply chain design for solid waste recycling under uncertainties and carbon emission constraint', Waste Management, Vol. 64, pp.358-370.

Ye, F., Li, Y. and Yang, Q. (2016) 'Designing coordination contract for biofuel supply chain in China', Resources, Conservation and Recycling, Vol. 128, pp.306-314.

Yehia, A.A., Mull, M.A., Ismail, M.N., Hefny, Y.A. and Abdel-Bary, E.M. (2004) 'Effect of chemically modified waste rubber powder as a filler in natural rubber vulcanizates', Journal of Applied Polymer Science, Vol. 93 No. 1, pp.30-36.

Yeon, J.-O., Kim, K.-W., Yang, K.-S., Kim, J.-M. and Kim, M.-J. (2014) 'Physical properties of cellulose sound absorbers produced using recycled paper', Construction and Building Materials, Vol. 70, pp.494-500.

Yu, X., Tao, Z., Song, T.-Y. and Pan, Z. (2016) 'Performance of concrete made with steel slag and waste glass', Construction and Building Materials, Vol. 114, pp.737-746.

Zabaleta, I. and Rodic, L. (2015) 'Recovery of essential nutrients from municipal solid waste - Impact of waste management infrastructure and governance aspects', Waste Management, Vol. 44, pp.178-187.

Zetterholm, J., Pettersson, K., Leduc, S., Mesfun, S., Lundgren, J. and Wetterlund, E. (2018) 'Resource efficiency or economy of scale: Biorefinery supply chain configurations for co-gasification of black liquor and pyrolysis liquids', Applied Energy, Vol. 230, pp.912-924. 
Supply network configuration archetypes for the circular exploitation of solid

waste

Zhang, Z., O’Hara, I.M., Mundree, S., Gao, B., Ball, A.S., Zhu, N., Bai, Z. and Jin, B. (2016) 'Biofuels from food processing wastes', Current Opinion in Biotechnology, Vol. 38, pp.97-105.

Zhao, L., Wei, W., Bai, H., Zhang, X. and Cang, D. (2015) 'Synthesis of steel slag ceramics: Chemical composition and crystalline phases of raw materials', International Journal of Minerals, Metallurgy, and Materials, Vol. 22 No. 3, pp.325333.

Zijp, M.C., Posthuma, L., Wintersen, A., Devilee, J. and Swartjes, F.A. (2016) 'Definition and use of Solution-focused Sustainability Assessment: A novel approach to generate, explore and decide on sustainable solutions for wicked problems', Environment International, Vol. 91, pp.319-331.

Zissis, D., Ioannou, G. and Burnetas, A. (2015) 'Supply chain coordination under discrete information asymmetries and quantity discounts', Omega, Vol 53, pp.21-29.

Zissis, D., Saharidis, G., Aktas, E. and Ioannou, G. (2018) 'Emission reduction via supply chain coordination', Transport Research Part D: Transport and Environment, Vol. 62, pp. 36-46.

Zuccheratte, A.C.V., Freire, C.B. and Lameiras, F.S. (2017) 'Synthetic gravel for concrete obtained from sandy iron ore tailing and recycled polyethyltherephtalate', Construction and Building Materials, Vol. 151, pp.859-865. 
Response to the report of Reviewer \#A

We would like to thank the Reviewer \#A for his/her thorough reading of our previous manuscript version and for his/her positive feedback and constructive remarks. Below, we address the comment made by the referee:

\section{Comments}

1. The authors should clarify the terms used in the figures (e.g. "secondary supply") to increase clarity and better communicate the network configuration archetypes and its practical implications.

Answer: Done. In each subsection we exemplify the role of secondary suppliers in the proposed circular supply chain configuration archetype.

2. Authors should provide a short description on the operational side per each network configuration. This will provide greater rigor to the manuscript.

Answer: Done. In the revised version of the manuscript in Section "5 Conclusions" we now insert Table 7 "Circular supply chain archetypes and network configuration attributes" that compares collectively the three proposed circular supply chain configuration archetypes that further indicate operational characteristics per each network configuration archetype. In addition, Subsection 5.2 "Practical implications" describes the operationalisation of the identified archetypes.

3. The authors are recommended to update the scope of the paper with recent articles (i.e. published in 2019).

Answer: Done. We have updated the scope of the manuscript by citing recently published articles, to support the theoretical background and configurational perspective underpinning this research, including:

- Abdel-Shafy, H.I. and Mansour, M.S.M. (2018) 'Solid waste issue: Sources, composition, disposal, recycling, and valorization', Egyptian Journal of Petroleum, Vol. 27, pp.1275-1290.

- $\quad$ Batista, L., Bourlakis, M., Smart, P. and Maull, R. (2018) 'In search of a circular supply chain archetype - a content-analysis-based literature review', Production Planning and Control: The Management of Operations, Vol. 29, pp.438-451.

- $\quad$ Das, S., Lee, S.-H., Kumar, P., Kim, K.-H., Lee, S.S. and Bhattacharya, S.S. (2019) 'Solid waste management: Scope and the challenge of sustainability', Journal of Cleaner Production, Vol. 228, pp.658-678.

- Erfani, S.M.H., Danesh, S., Karrabi, S.M., Shad, R. and Nemati, S. (2018) 'Using applied operations research and geographical information systems to evaluate effective factors in storage service of municipal solid waste management systems', Waste Management, Vol. 79, pp.346-355.

- Singh, A. (2019) 'Managing the uncertainty problems of municipal solid waste disposal', Journal of Environmental Management, Vol. 240, pp.259-265.

- Tsolakis, N., Bam, W., Srai, J.S. and Kumar, M. (2019) 'Renewable chemical feedstock supply network design: The case of terpenes', Journal of Cleaner Production, Vol. 222, pp.802-822.

- Tziantopoulos, K., Tsolakis, N., Vlachos, D. and Tsironis, L. (2019) "Supply chain reconfiguration opportunities arising from additive manufacturing 
Supply network configuration archetypes for the circular exploitation of solid waste

technologies in the digital era", Production Planning and Control: The Management of Operations, Vol. 30, pp.510-521.

- Zetterholm, J., Pettersson, K., Leduc, S., Mesfun, S., Lundgren, J. and Wetterlund, E. (2018) 'Resource efficiency or economy of scale: Biorefinery supply chain configurations for co-gasification of black liquor and pyrolysis liquids', Applied Energy, Vol. 230, pp.912-924.

- Zissis, D., Saharidis, G., Aktas, E. and Ioannou, G. (2018) 'Emission reduction via supply chain coordination", Transport Research Part D: Transport and Environment, Vol. 62, pp. 36-46.

4. The border around figures needs to be removed.

Answer: Done. All figures have been edited and inserted in high quality within the revised version of the manuscript. The borders around the figures have been removed.

5. There are few typos throughout the manuscript that need to be corrected. Would suggest the authors proof-read the manuscript.

Answer: Done. The manuscript has been proof-read and minor typos have been eliminated. 
Response to the report of Reviewer \#B

We would like to thank the Reviewer \#B for his/her thorough reading of our previous manuscript version and for his/her positive feedback and constructive remarks. Below, we address the comment made by the referee:

\section{Comments}

1. The first RQ on potential material for CE is a work of itself and has already been discussed elsewhere in other general papers and textbooks under keywords as "recyclable/reuseable materials". The second RQ seems to be the novelty of this paper. However, certain aspects are still unexplained.

Answer: We would like to thank Reviewer \#B for this constructive and very interesting comment. In the revised version of the manuscript we have removed the initial Research Question 1. We now focus only on one Research Question that considers the circular network configuration archetypes. In the revised version of the manuscript we still keep the literature review on the potential solid waste streams that could act as renewable feedstock in circular supply chains and we clearly link them to the proposed configuration archetypes through Table 7 "Circular supply chain archetypes and network configuration attributes".

2. Besides biofuel, biogas produced from organic waste is also a product from organic waste? Is there a reason why this product is not specifically mentioned?

Answer: We would like to thank Reviewer \#B for this comment. Biogas is a type of biofuel that is naturally produced from the decomposition of organic waste. As the purpose of this research is not to exhaustively investigate each particular product that can derive from renewable feedstocks, we do not explicitly refer to biogas. We indirectly refer to that through the umbrella term of biofuels.

3. Why was geographical dispersion chosen as a basis for the network archetypes? Please explain.

4. The methodology could detail more on how the network archetypes were established.

Answer: Done. In the revised version of the manuscript in Subsection "2.2 Theoretical lens" we now clarify the selection of the geographical dispersion as a basis for the network archetypes and how the network archetypes were established by stating that:

"The circular supply network configuration archetypes identified in this research are based on the level of the geographic dispersion of operations. In other words, based on a graph-theoretic perspective, a configuration archetype in this research is characterised as the proximity of nodes (renewable material sources and processing facilities) and arcs (transportation) for the valorisation of wasted solid material that further affects the associated network performance and sustainability repercussions (Kim et al., 2015). In this sense, considering the centrality of the manufacturing node for the provision of value-added intermediates or end-products, three circular supply network archetypes are proposed: (i) centralised; (ii) semi-centralised; and (iii) decentralised. The alternative network configurations can then be evaluated in terms of (Zetterholm et al., 2018): network objective; operational constraints imposed by the physico-chemical properties of the solid waste; technology and processing constraints; transportation and 
Supply network configuration archetypes for the circular exploitation of solid waste

scheduling requirements; expected trade-offs, i.e. processing efficiency, economy of scale effects and financial viability; environmental sustainability impact.

The geographical attribute is dominant in solid waste valorisation networks considering the: (i) geographical distribution and pooling of diverse solid waste sources that dictate network optimisation objectives, e.g. supply capacity, number of collection/processing facilities, network capacity etc. (Erfani et al., 2018); (ii) geographical restrictions on solid waste logistics/transportation (Das et al., 2019); (iii) alternative legislatively and technically imposed requirements for the transportation and treatment of different solid waste in a range of geographical regions (Abdel-Shafy and Mansour, 2018); (v) variant level of infrastructure and technology readiness for solid waste collection, transportation and treatment (Zabaleta and Rodic, 2015); and (iv) local and regional environmental impact of solid waste (Singh, 2019)."

5. As mentioned in page 12, the network should also focus on scope. How is the scope of each aspect in the archetypes?

Answer: Done. In the revised version of the manuscript in Section "4 Circular Supply Network Configurational Archetypes" we now clarify that:

"The scope of the proposed network archetypes varies and depends on the market to be served. In particular, centralised circular supply network archetypes serve global markets whereas decentralised networks usually target regional markets. In semicentralised network archetypes nodes have different levels of operational autonomy to serve glocal market needs."

6. The discussion section could detail more on the comparison between the 3 archetypes and the advantage and disadvantage between the three.

Answer: Done. In the revised version of the manuscript in Section "5 Conclusions" we now insert Table 7 "Organic waste as feedstock to key circular value network applications" that compares collectively the three proposed circular supply chain configuration archetypes.

7. There references for Network Archetypes refer mostly to papers by Srai. Are there any other authors that can quoted by this paper?

Answer: Done. In this research we adopt the network configuration perspective proposed by Srai et al. to propose circular supply chain archetypes. Extant literature on supply chain configurational archetypes is very limited. In the revised version of the manuscript, in Subsection "2.2 Theoretical lens", we also refer to the seminal works from Kim et al. (2015) to support our viewpoint:

- Kim, Y., Chen, Y.-S. and Linderman, K. (2015) 'Supply network disruption and resilience: A network structural perspective', Journal of Operations Management, Vol. 33-34, pp.43-59.

We could only identify the work by Batista et al. (2019) in which the authors articulate five propositions regarding circular supply chain archetypes; they identify 'scope', 'focus' and 'impact' as the explanatory perspectives:

- $\quad$ Batista, L., Bourlakis, M., Smart, P. and Maull, R. (2018) 'In search of a circular supply chain archetype - a content-analysis-based literature review', Production Planning and Control: The Management of Operations, Vol. 29, pp.438-451. 
N. Tsolakis et al.

In contrast, our research focuses on configuration as the underpinning archetypal form of circular supply networks. 